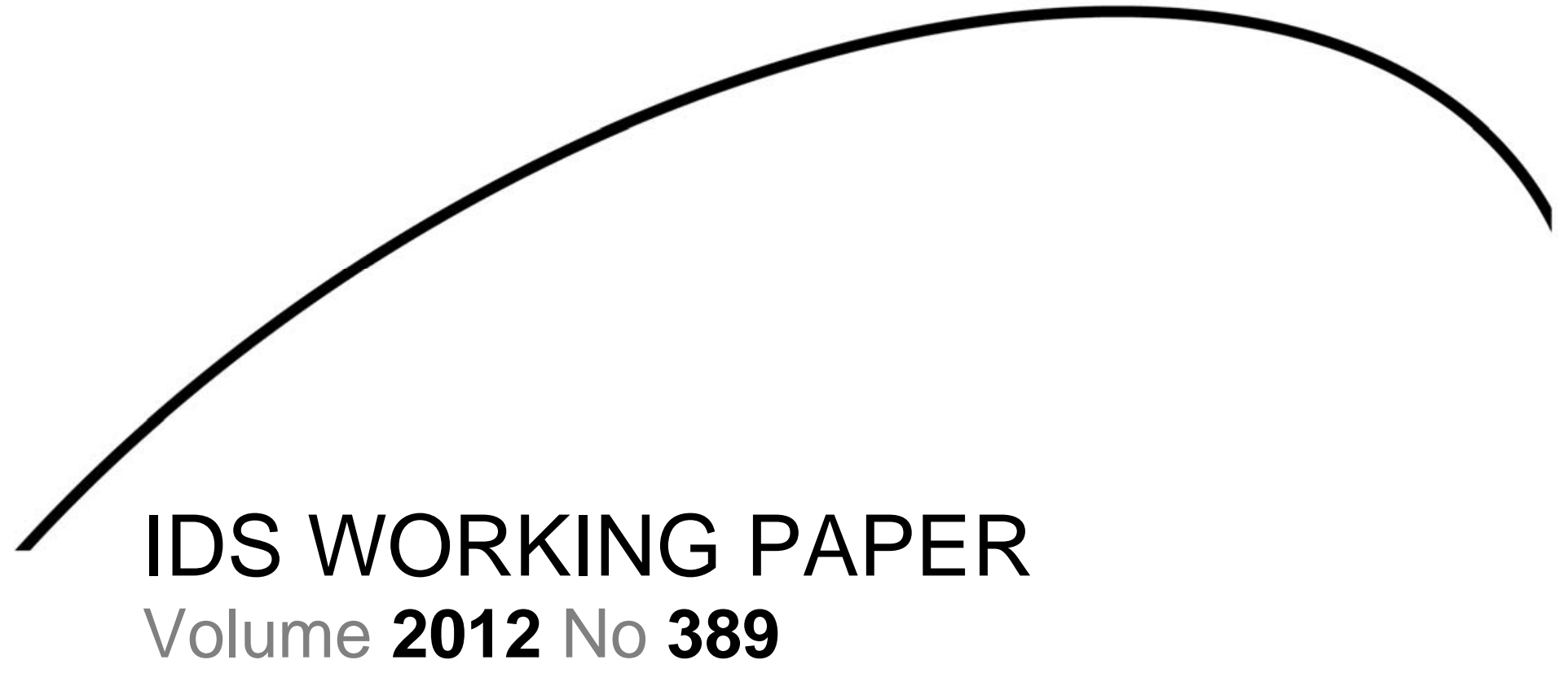

Women's Empowerment Revisited:

From Individual to Collective Power among the Export Sector Workers of Bangladesh

Naomi Hossain

March 2012 
Women's Empowerment Revisited: From Individual to Collective Power among the Export Sector Workers of Bangladesh Naomi Hossain

IDS Working Paper 389

First published by the Institute of Development Studies in March 2012

(C) Institute of Development Studies 2011

ISSN: 2040-0209 ISBN: 978-1-78118-046-4

A catalogue record for this publication is available from the British Library.

All rights reserved. Reproduction, copy, transmission, or translation of any part of this publication may

be made only under the following conditions:

- with the prior permission of the publisher; or

- with a licence from the Copyright Licensing Agency Ltd., 90 Tottenham Court Road, London

W1P 9HE, UK,

or from another national licensing agency; or

- under the terms set out below.

This publication is copyright, but may be reproduced by any method without fee for teaching or nonprofit purposes, but not for resale.

Formal permission is required for all such uses, but normally will be granted immediately. For copying in any other circumstances, or for re-use in other publications, or for translation or adaptation, prior written permission must be obtained from the publisher and a fee may be payable.

\section{Available from:}

Communications Unit, Institute of Development Studies, Brighton BN1 9RE, UK

Tel: +44 (0) $1273915637 \quad$ Fax: +44 (0) 1273621202

E-mail: bookshop@ids.ac.uk

Web: www.ids.ac.uk/ids/bookshop

IDS is a charitable company limited by guarantee and registered in England (No. 877338) 


\title{
Women's Empowerment Revisited: From Individual to Collective Power among the Export Sector Workers of Bangladesh
}

\author{
Naomi Hossain ${ }^{1}$
}

\section{Summary}

Bangladesh has become known as something of a success in advancing gender equality since the 1990s. There have been rapid gains in a number of social and economic domains, yet by most objective standards the current condition and status of women and girls within Bangladeshi society remain low. Rapid progress has come about under conditions of mass poverty and interlocking forms of social disadvantage, political instability and underdevelopment, overlain with persistent 'classic' forms of patriarchy. Mass employment of women and girls in the country's flagship export sector - the readymade garments (RMG) sector - has been one of the more visible and prominent changes in women's lives since its late 1970s' introduction.

Whether and the extent to which RMG or garments employment has changed the lives of women workers for the better has been the subject of much debate, and the research and analysis it has generated offers valuable insights into the processes of economic and social empowerment for poor women in low income developing countries. Yet as this paper notes, close observers of social change in Bangladesh have become dissatisfied with the limits of a focus on individual economic empowerment. Paid work may enable some women to negotiate the 'structures of constraint' that shape their lives and relationships, but what of the structures of constraint themselves? In the Bangladesh context the experience of mass RMG employment has given rise to questions about whether women have gained greater recognition as citizens with rights and roles as carers in the private and political actors within the public spheres. Revisiting the question of women's empowerment in this context means interrogating whether paid employment has contributed to investments in the education and skills of women and girls, improvements in their public safety and rights to occupy public space. Given labour militancy in the sector and its partial successes in raising the minimum wage, what has the experience of labour politics meant for women's political empowerment?

Drawing mainly on the rich literature available on women's RMG employment, this paper explores the wider and less well-documented effects of such employment on public policy relating to gender equality in these areas. It concludes that the overall direction of change in the industry points plainly to the need for investments in worker productivity, with a host of implications for women's work and gender equality more broadly. Factory owners have to date shown few signs of recognising their interests in supporting better state health, education and public safety for women and girls, or changing management practices to retain and raise productivity of skilled women workers. Yet with downward pressure on wages increasingly effectively resisted by workers at a time of global economic volatility and rising living costs, the tide may now be turning for the RMG workers of Bangladesh. Productivity gains require the state and the industry to treat women workers as full citizens with public policies that promote their skills and safety and respect, and which guarantee the representation of their rights and demands. RMG employment continues to be a source of empowerment for women in Bangladesh, but social and economic change means that that power now depends less on the individual economic effects of paid work on household decision-making than it once did. RMG employment is increasingly a source of power for women because of its more collective effects on women's citizenship and political agency. This matters all the more because of how this group is exposed to the volatilities of the global economy. 


\section{Contents}

Summary 3

Acknowledgements and Disclaimer $\quad 5$

1 Introduction: the state of women's empowerment in Bangladesh 6

$\begin{array}{ll}1.1 & \text { The idea of success }\end{array}$

$\begin{array}{ll}1.2 & \text { Social indicators } \\ 1.3 & 7\end{array}$

1.3 Economic participation 8

$\begin{array}{lll}1.4 & \text { Political participation and security } & 10\end{array}$

$\begin{array}{ll}1.5 & \text { Changing society in the post-conflict era } \\ 11\end{array}$

$\begin{array}{ll}1.6 & \text { Empowerment revisited } \\ & 13\end{array}$

2 The RMG sector 14

2.1 The economic significance of the RMG sector 15

2.2 The political significance of the RMG sector 15

$3 \quad$ Women as RMG workers 17

$\begin{array}{ll}3.1 \text { Hard work } & 18\end{array}$

3.2 Workers' experiences of economic and social empowerment through garments work 21

$\begin{array}{ll}\text { 3.3 Women's wages and male power } 23 & 21\end{array}$

$4 \quad$ The wider effects of RMG employment 24

4.1 The impact on men's attitudes 24

4.2 RMG employment and the expansion of basic education for girls 25

4.3 Women's mobility and the feminisation of public space 27

$\begin{array}{ll}4.4 & \text { Citizenship and political empowerment } 28\end{array}$

5 Conclusions 30

$\begin{array}{ll}\text { Annex } & 31\end{array}$

References 33

Tables

Table 1.1

Table 1.2

Table 3.1

Table 3.2

Selected changes in Bangladeshi women's health and education $\quad 7$

Years of education in the labour force by quintile 2000-5 9

Gender division of RMG jobs (\% of workers) 19

Workers' reports of incidents that contribute to insecurity

(\% of workers)

20

\section{Figures}

Figure 1.1 Labour force participation rates for men and women, 1999-2000 and 2005-6

Figure 1.2 Proportion of seats held by women in national parliament, 1990-2009 


\section{Acknowledgements}

The author is grateful to Carolina Sanchez-Paramo and Sudhir Shetty of the World Development Report Team for comments on the first draft, Samer Al-Samarrai for insights into the issue of education and skills, and colleagues at BRAC Development Institute, in particular Ferdous Jahan, Sohela Nazneen and Mamunur Rashid for work done jointly on women's empowerment (Nazneen et al. 2010; 2011) and on the effects of the food, fuel and financial crisis (Hossain et al. 2009; Hossain et al. 2010). The work with BDI colleagues has generated many of the insights into the wider context of women's empowerment, and the recent global economic shocks experienced by garments workers discussed in this paper. Useful comments were also received from colleagues at the Dhaka World Bank office. The author is particularly grateful to Sohela Nazneen for her insights and knowledge of relevant recent literature and public perceptions of garments workers.

\section{Disclaimer}

While a version of this paper was originally prepared as a background paper for the World Development Report 2012 on Gender Equality and Development, it does not reflect the views of the World Bank. All errors and omissions are those of the author alone.

An earlier version has been published as: 'Exports, Equity, and Empowerment: The Effects Of Readymade Garments Manufacturing Employment On Gender Equality In Bangladesh', http://siteresources.worldbank.org/INTWDR2012/Resources/7778105-

1299699968583/7786210-1322671773271/Hossain-Export-Equity-employment.pdf 


\section{Introduction: the state of women's empowerment in Bangladesh}

This paper is going to try to assess the effects of RMG employment on women's empowerment in Bangladesh. To do so, it will start by setting out evidence of change in women's lives in Bangladesh, as well as of areas of persistent disadvantage and domination. It will present some perspectives on what these changes mean, and in so doing set out some markers for the future direction of analysis of women's empowerment in this setting.

\subsection{The idea of success}

Bangladesh has come to be seen as a success in promoting gender equality in recent years. A recent study summarised it as follows:

Bangladesh stands out as the shining new example in South Asia of a poor country achieving impressive gains in gender equality ... a country that had been famously written off by Henry Kissinger as a 'basket case,' which now dwarfs India and Pakistan in many areas.

Between 1971 and 2004, Bangladesh halved its fertility rates. In much of the country today, girls' secondary school attendance exceeds that of boys. The gender gap in infant mortality has been closed. The micro-credit revolution continues to boost women's solidarity groups and earning potential, and vast numbers of young women are leaving their villages to work in garment factories where, in earlier generations, young women were rarely seen outside their homes.

(World Bank 2008a: 3)

Other donor documents similarly note 'first generation' achievements towards gender equality, typically with reference to gender parity in basic education, Bangladesh's 'pioneering' role in micro-credit, and formal sector employment of two million young women in the readymade garments (RMG) industry (Nazneen et al. 2011).

The official view is a moderate version of the same. The Government's recent National Strategy for Poverty Reduction document noted that '[w]omen in Bangladesh have made important gains along with changes in social attitudes towards women's economic participation' (Government of Bangladesh 2009a: 3):

[M]easurable progress in women's advancement and rights in a number of areas including education, participation in labour force, health and nutrition, and participation in public services. In the area of women's advancement and rights, the government has made strong commitments and undertaken various initiatives to reduce the gap between men and women.

(Government of Bangladesh 2009a: 62)

The idea of successful progress towards gender equality could be read as a comment on the unpromising context in which these rapid changes have taken place, characterised by chronic mass, severe and interlocking forms of poverty and disadvantage (Sen and Hulme 
2006); political instability and weak governance (IGS 2006; 2008), and persistent 'classic' forms of patriarchy. ${ }^{2}$

The idea of success chimes to some extent with perspectives from the women's movement. For the women's movement, progress in the present era is slower compared to the 1990s' 'golden age' of democratic transition (Nazneen and Sultan 2010: 70). There are also signs that advances can be reversed, and the growing influence of conservative versions of Islam on national politics and society are cited (ibid.). The mood in the women's movement is more cautious; having itself emerged out of the two-part national struggles for independence, the women's movement has a healthy respect for the possibilities of change through mobilisation and collective action, and extensive experience of negotiating tricky political terrain. So the feminist struggle continues.

\subsection{Social indicators}

What is the substance of this success, and what are the remaining challenges? In 2010, Bangladesh ranked $116^{\text {th }}$ in the Gender Inequality Index of the UNDP's Human Development Index, below Pakistan's 112, yet above India's 122 (UNDP 2010); even within South Asia, then, it is not apparent that Bangladesh has much to celebrate in terms of the levels of gender equality (nor, indeed, Pakistan or India). Yet the pace of change merits attention: gains for Bangladeshi women were made from a lower starting point, and caught up fast given the modest pace of poverty reduction, particularly in the 1990s. Table 1 summarises key changes in health and education indicators over the last three decades.

Table 1.1 Selected changes in Bangladeshi women's health and education

\begin{tabular}{l|l}
\hline Indicator & Outcome \\
\hline Fertility & Total fertility rate declined from $7.3(1974)$ to $2.7(2007)^{1}$ \\
$\begin{array}{l}\text { Maternal } \\
\text { mortality }\end{array}$ & $\begin{array}{l}\text { Maternal mortality ratio (maternal deaths per 100,000 live births) more than halved from } 648 \\
(1986) \text { to } 315(2001)^{2}\end{array}$ \\
$\begin{array}{l}\text { Basic } \\
\text { education }\end{array}$ & $\begin{array}{l}\text { Gender parity in primary and secondary enrolment achieved by early 2000s; girls now outnumber } \\
\text { boys }^{3}\end{array}$ \\
\hline $\begin{array}{l}\text { Sources: } \\
1\end{array}$ & NIPORT (2009) \\
3 & World Bank (2007)
\end{tabular}

The most striking changes have been seen with respect to girls' education. Bangladesh closed the gender gap in enrolment at primary by the end of the 1990s, ahead of the MDG targets and many comparator countries (Chowdhury et al. 2002). More girls than boys now enrol in secondary school, drawn in substantial part, it is believed, by the availability of cash stipends for all unmarried girls who attend and perform to a minimum level (Al-Samarrai 2009). Yet while Bangladesh has done well compared to other countries in widening girls' access to school, quality and attainment for boys and girls are absolutely low and the closure of the gender gap in basic education may reflect stagnating educational access among the 'boys left behind' (World Bank 2008a; Shafiq 2009; Tariquzzaman and Hossain 2009). After the rapid progress of the 1990s, Bangladesh's more recent MDG performance has been disappointingly average.

Kandiyoti's (1988) term refers in the Bangladesh context to a society characterised by 'patrilineal principles of descent, patriarchal structures of family organization, the practice of female seclusion, and a marked preference for sons over daughters' (Kabeer 2004: 14). 


\subsection{Economic participation}

Patterns of women's economic participation have changed fast. Women's labour force participation rate grew faster than that of men in the 1984-2000 period (Rahman 2005), yet remained comparatively low at 22.8 per cent in 2000 (25.6 in urban areas). However, women's wage employment increased considerably after that, growing at 4.3 per cent each year between 2000 and 2005 (World Bank 2008b; see also Figure 1).

Figure1.1 Labour force participation rates for men and women, 1999-2000 and 2005-6

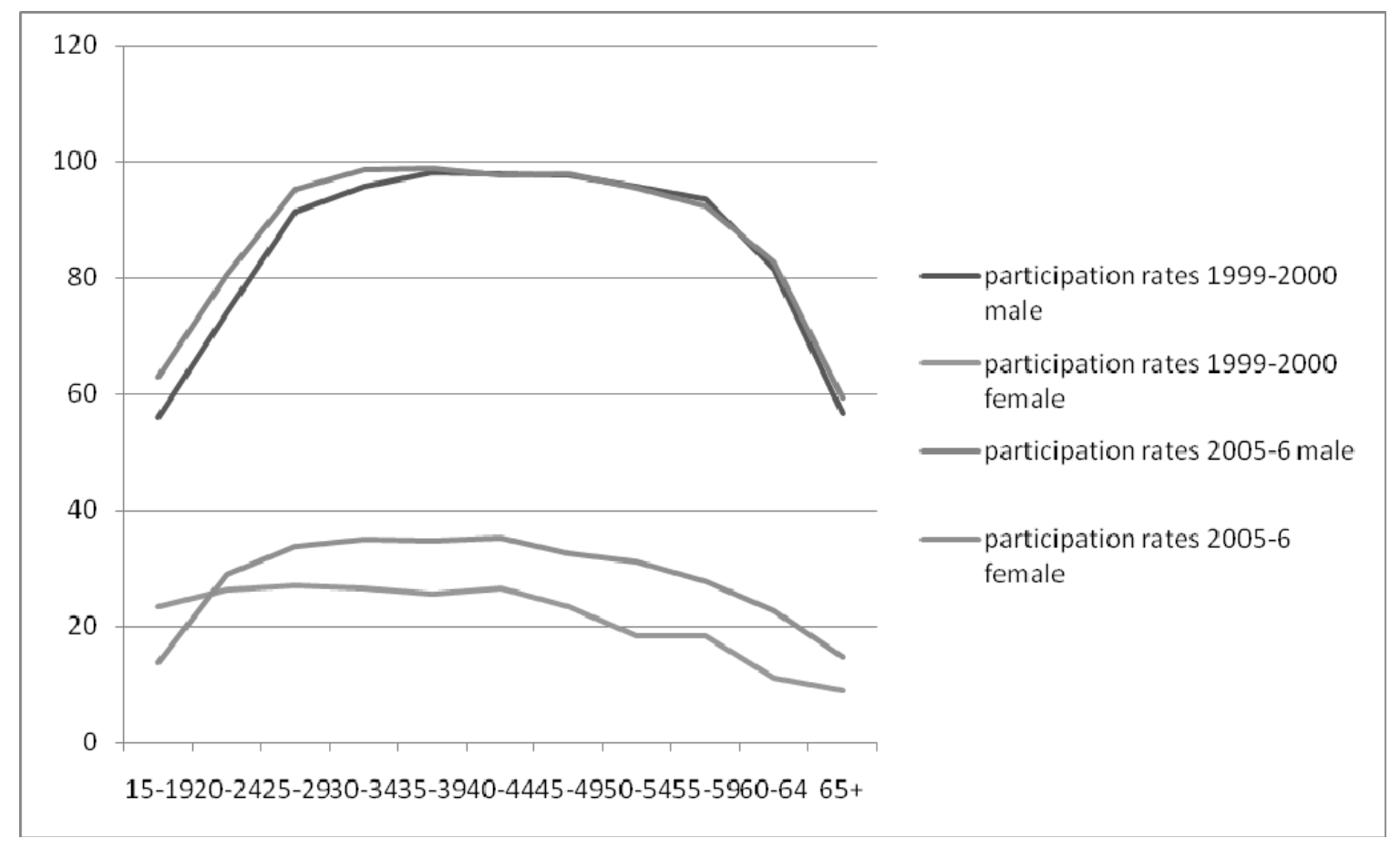

Source: Labour Force Survey 1999-2000; 2005-06 (BBS 2002; 2008)

In relation to girls' increased access to education it is worth noting that official figures suggest that labour force participation rates for younger women (aged 15 to early 20 s) actually declined during the early 2000s. This suggests that more women in this age group were entering education in preference to early entry into the low-skill end of the workforce. This would be consistent with the finding that the gender wage gap narrowed at the upper end in the first half of the 2000s, as higher educated women gained access to employment (particularly in the public sector; Al-Samarrai 2007). The narrowing of the gender wage gap reversed the pattern of change over the second half of the 1990s, in which the share of women's formal sector employment shrank from 20.8 (1995-96) to 8.9 (1999-2000) per cent (Rahman 2005). The result of this shift has been that women's wages increased much faster than men's over the first half of the 2000s, and the gender gap in income and wages narrowed considerably, particularly at the upper end of the occupation hierarchy (Al-Samarrai 2007). This was substantially to do with the changing composition at the top end of the female labour force: of the richest 20 per cent of women, 58 per cent had been in salaried work (e.g., skilled public sector employment) and 26 per cent self-employed in agriculture in 2000; these proportions changed to 76 per cent in salaried work and only 3 per cent selfemployed in agriculture in 2005 (Al-Samarrai 2007). In short, there are not only more women in paid work in Bangladesh than in the past, they are also increasingly concentrated in formal sector employment. 
A critical factor in the narrowing of the gender wage gap appears to have been gains in education (see table 2). However, as recent real wage and income gains for women have been concentrated among the more educated and typically more affluent population, there will have been more limited impacts for poor women. And despite these gains for women who have succeeded in catching up with men educationally, on average, women continue to earn 21 per cent less per hour than men (Kapsos 2008). A considerable proportion of the gender wage gap remains explained by simple discrimination, as well as by labour market segmentation that excludes women from better-paid occupations (Ahmed and Maitra 2010; Kapsos 2008).

Table 1.2 Years of education in the labour force by quintile 2000-5

\begin{tabular}{|l|l|l|l|l|l|l|}
\hline quintile & \multicolumn{3}{|c|}{2000} & \multicolumn{3}{c|}{2005} \\
\hline & male & Female & total & male & female & total \\
\hline 1 & 1.6 & 0.6 & 1.4 & 2.0 & 1.4 & 1.9 \\
\hline 2 & 2.2 & 1.2 & 2.1 & 2.7 & 1.5 & 2.6 \\
\hline 3 & 3.0 & 1.7 & 2.9 & 3.7 & 3.1 & 3.7 \\
\hline 4 & 4.5 & 3.4 & 4.4 & 5.3 & 4.7 & 5.3 \\
\hline 5 & 7.7 & 6.8 & 7.6 & 8.6 & 8.4 & 8.5 \\
\hline Total & 3.9 & 2.7 & 3.8 & 4.6 & 4.0 & 4.5 \\
\hline
\end{tabular}

Source: Al-Samarrai (2007) based on HIES data

Some 60 per cent of the increase in women's paid work during the 2000s was concentrated in urban areas, half overall in manufacturing sectors. Over two million women are estimated to be employed in the RMG industry, which dominates the Bangladesh manufacturing export sector. Given that garment factory careers may be short, many more than the current two million women are likely to have experienced factory work over their lifetimes, so that the social effects of RMG employment are likely to have been more widely shared across the population than the two million figure suggests. There has also been significant recent growth in public sector employment as teachers or health workers, and in self-employment and household enterprises, often in response to public policy measures to recruit women in order to better advance gender equality goals in the social sectors (health, education, fertility control and poverty reduction).

An older, much-debated pathway of women's economic empowerment has been microcredit, in which the scale of Bangladeshi women's collective participation has been unprecedented. Micro-finance programmes for women expanded fast from the second half of the 1990s; by 2006, it was estimated that there were some 16.4 million micro-credit borrowers in Bangladesh, the overwhelming majority of them women; the Government of Bangladesh is itself a major source of wholesale financing for micro-credit and of credit programmes (World Bank, 2006). Debates about the impacts of micro-credit on women's empowerment have rehearsed themes around control over resources and the effects on women's domestic bargaining power (Goetz and Sen Gupta 1996; Kabeer 1999). Despite enduring scholarly scepticism about the benefits of micro-finance, it features prominently in domestic development debates as a strategy for addressing vulnerability and poverty. Evidence is available to show a range of empowering effects, including that participation in micro-finance programmes enabled discussion of family planning with spouses, an expanded role in household decision making, more access to 'financial, economic, and social resources' and greater mobility (World Bank 2006: 24). In relation to intra-household relations and women's economic empowerment, the 2007 Demographic and Health Survey found that while fewer women reported making decisions about the use of their income alone 
than in 2004 (from 39 to 31 per cent), the proportion of women claiming involvement in joint decision making had risen, from 47 to 56 per cent (NIPORT, 2009). There are some good reasons to believe that the economic roles within Bangladeshi gender relations have experienced a significant shift, and that micro-credit has played a part in that. More recent concerns about possible market saturation and serial indebtedness have shifted attention to the problem of too much, as opposed to too little, access to finance.

\subsection{Political participation and security}

In contrast to their striking gains in human development and new economic opportunities, and despite the two top political leaders both being women, Bangladeshi women have fared far less well with respect to their political participation at the centre than women in comparator countries (see figure 2).

Figure 1.2 Proportion of seats held by women in national parliament, 1990-2009

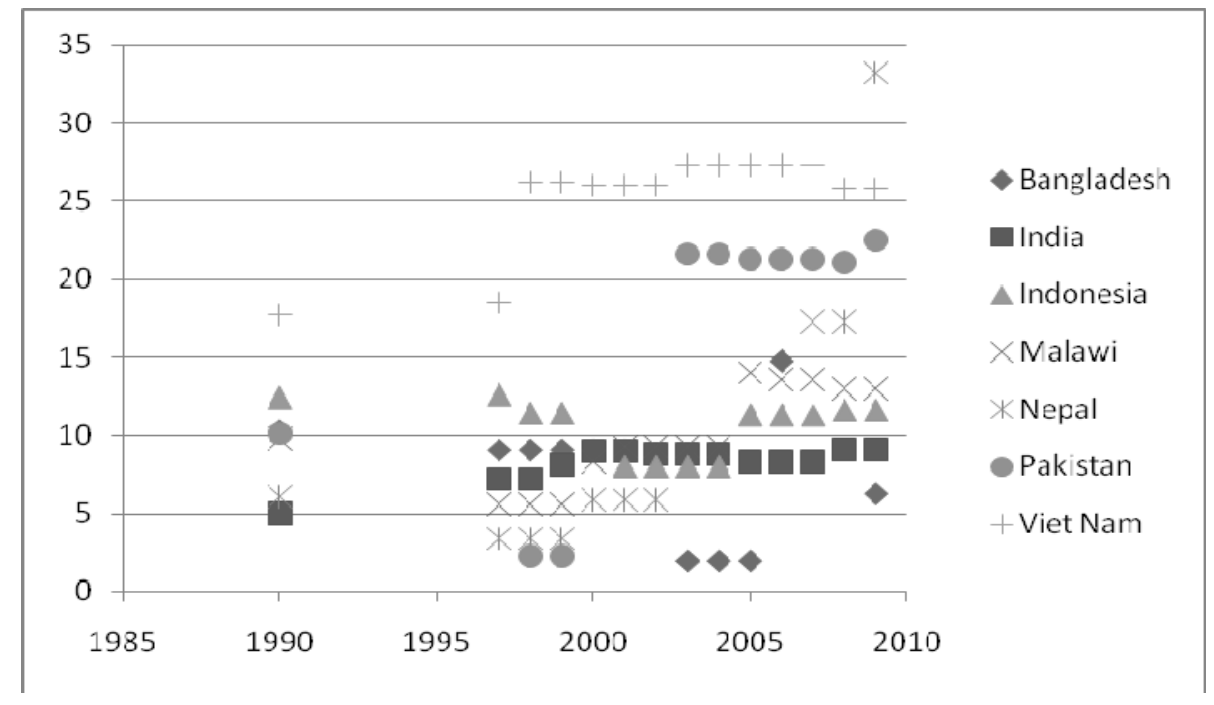

Source: UNSTATS UN Millennium Development Goals Indicators (http://mdgs.un.org/unsd/mdg/Default.aspx)

The provision of reserved seats has ensured 30 per cent representation of women in local and national government, but few women have won party endorsement to contest general seats. In the last parliamentary election, 17 women won general seats - by far the highest figure in all parliamentary elections to date (the previous record being 8 in 2001, suggesting an upward trend from an abysmally low starting point (Pandey 2008). Many women candidates are, however, believed to be proxies contesting on behalf of disqualified or jailed male family members. All political parties have delayed introducing direct elections to women's reserved seats in Parliament, since these seats are valuable patronage resources, particularly during coalition negotiations.

In terms of women's access to justice and security, the most persistent concern is about the prevalence of violence against women. The most recent DHS data indicate that 49 per cent of ever-married women had experienced some spousal physical violence in their most recent marriage; 18 per cent had experienced rape within marriage; 53 per cent had experienced some form of physical and/or sexual violence, while 13 per cent had experienced both (NIPORT 2009: 201). While the evidence does not indicate violence against women has increased over time, ${ }^{3}$ evidence from the WHO (2005) multi-country study and other research

Focus group discussions about domestic violence as part of research for the World Bank's gender survey did not indicate a perceived rise in domestic violence (World Bank 2008a: 92). It seems likely that the efforts of the women's 
indicates that Bangladeshi society suffers from a comparatively high prevalence of violence against women (Naved et al. 2006). A series of different sources have arrived at similar estimates of the prevalence of domestic violence, including that between 40 per cent and half of all women experience violence from husbands in their life time, with the proportion rising to two-thirds among poorer groups; in addition, just under one-fifth of married women of reproductive age (16-19 per cent) experienced current or recent violence from husbands (cited in Naved and Persson 2010).

\subsection{Changing society in the post-conflict era: dowry, violence and the feminisation of public space}

The larger social backdrop to the above changes in women's lives was that of the dislocation to gender norms associated with the war in 1971 and the post-conflict period. This period was catastrophic for many hundreds of thousands of families, so much so that the destruction of old certainties and customs may well have primed gender relations for the rapid social and economic change that followed. ${ }^{4}$ This was a period in which the assurances of male protection under the 'patriarchal bargain' became shakier. The account of one early entrant into the RMG industry illustrates the situation in which many women found themselves in the post war period:

During the [1971] troubles, my husband and father were murdered by the razakars ... My son was just over a year old then. We never found their bodies ... My mother and sister died of illness. I had two brothers, one drowned and the other died of illness. All of them are dead ... I have no one left.

(Kabeer 2000: 102)

An unknown number of women were raped during the war, possibly as many as several hundred thousand $;^{5}$ many more experienced trauma, displacement, and the loss of fathers, brothers, husbands and sons (Kabeer 2000). Women had themselves been prominent within the nationalist struggle - a formative experience for important sections of the women's movement. Yet the most significant state response was to rewrite the patriarchal bargain as one between (victimised) women and the state through the 'birangona' programme intended to socially rehabilitate the women raped during the war by declaring them war heroines and arranging marriages for them (Kabeer 1991a). As Mookherjee notes 'the kinship norms of purity and honour were articulated in a public discourse that made [the women who had been raped] the concerns not merely of the family or the community but also of the new nation' (2008: 40). Arguably we see in this first action an appropriation of the responsibility to act on behalf of women whose victimhood brought them directly within the jurisdiction of the state. It was soon after that the state began to experiment with social protection for women through the Vulnerable Group Development (VGD) programme; it seems likely that these shifts in the way the state 'saw' poor women at this time are related. The VGD was an innovation in its era, for among other reasons it targeted destitute women directly, rather than operating through male household heads (Hossain 2007). This could be reasonably interpreted as marking official recognition that the patriarchal bargain had broken down en masse for its most vulnerable citizens, and that it was, therefore, mandated to act.

movement to draw attention to this as an issue have borne fruit to the extent that it receives more attention and is spoken of as a problem, in contrast to the past.

War frequently involves sharp shifts in gender relations and related public policy (see Moghadam 2003).

The number of women raped during the Bangladesh liberation war has been the subject of recent controversy. Susan Brownmiller used the 300,000-400,000 estimate in her definitive account, Against our Will. Yet Germaine Greer, herself active in securing abortions for Bangladeshi wartime rape survivors in 1972, stated on television in 2011 that the wartime rapes in Bangladesh were 'an urban myth' (she may have been referring to the idea that rape was a Pakistani army policy). This bizarre volte-face is of course easily discounted by numerous credible sources which suggest that around 25,000 abortions and adoptions are known to have taken place; as these were generally concealed or undertaken in secret, the number of rape survivors is likely to have been far greater, in line with the official lists that were collected and later destroyed. Bina D'Costa and Nayanika Mookherjee have published recent analyses of these events. 
The rupture of the patriarchal bargain meant many women were in the position of having to support themselves. The famine and wider economic crisis that followed the war in the mid1970s produced growing evidence that women were seeking paid work outside the home 'in the face of considerable resistance from family and community' which still assumed a norm of female seclusion (Kabeer 2000: 65). The combination of women without male protection, acute poverty and deprivation and high fertility rates meant the country was 'a ripe field' for positioning women at the centre of development as beneficiaries and 'targets' (Azim 2001: 392).

Predating the war, longer-term processes of landlessness, impoverishment and new employment opportunities for educated men were also affecting the economic resources of women. These processes drove a reversal of marriage payments from the gifts to the bride's family (customary till the 1950s) towards payments to the groom's family - dowry or as is more commonly used, dabi (literally, 'demand') (Kabeer 2000). The persistent strength of the norm of universal and early marriage, particularly for women, means that dowry has become a significant burden across sections of society. This seems to be particularly true among poor households with many daughters. Recent research found that around 53 per cent of rural households and 14 per cent of urban households reported facing dowry demands (Naved and Persson 2010, based on 2001 data). It also seems that dowry demands are a relatively more serious problem among poorer people, with 61 per cent of rural women in the poorest quintile facing demands compared to 37 per cent in the top quintile; comparable urban figures were 20 per cent for the lowest and 7 per cent in the top quintile (ibid. pp. 841). This may not mean that richer households do not give and take dowry, but that they do so as 'gifts' and can generally afford to do so without serious damage to the household economy. A nationally representative survey by the new National Human Rights Commission of Bangladesh placed dowry at the top of the list of issues reported to be affecting women in 2011 (NHRCB 2011). Dowry or demand is a strikingly common source of discontent and insecurity for the society as a whole, which has to date eluded effective regulation or social change.

Amin argues that the necessity of marriage amidst a 'powerful perception of insecurity and risk of sexual violation of girls living in households without a male guardian' (1997: 230) coupled with the demands of dowry leave the poorest women vulnerable to marriages in which there is 'no obligation on the part of the man to support his wife' (ibid.) 'Dowry violence', including murders, immolations, suicide and other forms of violence has become categorised as a specific policy problem in the popular media and within official discourse (see references in Government of Bangladesh 2009a: 10-11, 62-3). Public opinion and public safety surveys now routinely return 'dowry' among the most pressing social issues of the day. The 1999 Bangladesh study for the World Bank's Voices of the Poor study consistently identified dowry as among men and women's key concerns in relation to poverty and gender relations (Nabi et al. 1999). A 2007 survey of human security found that some 56 per cent of respondents listed 'dowry' as among the crimes and insecurities they worried about most, second only to personal property crimes at 77 per cent (Saferworld 2008).

A final aspect of the wider social backdrop against which women's lives are being lived in $21^{\text {st }}$ century Bangladesh is the feminisation of public space, a much-commented on change exemplified by the visible urban fact of young women garments workers en masse en route to work. Other symbols of this feminisation of public space include the presence of large numbers of young girls going to school and college in rural areas and upazilas and small towns, as well as the by-now familiar figure of women NGO staff, some on motorcycles and bicycles, others walking or using public transport. Many wear head coverings of various kinds and styles, but by no means all do at all times, highlighting that this remains a matter of choice for women in Bangladesh. BRAC women staff have innovated an outfit which resembles a cross between a lab coat and burkah; this denotes their official and professional 
status without requiring that they cover their heads. A mobile phone billboard in 2011 features a confident smiling young woman cycling down a sun-dappled country lane - a gulf away from earlier imageries of women. We will look more at what this claiming of the right to move in public space has meant for gender relations in Bangladesh in relation to garments work more below. It should be noted that the immense cultural significance of women having gained access to the public sphere will be lost on anyone who cannot recall the Bangladesh of the 1980s or earlier.

\subsection{Empowerment revisited}

It is against this backdrop that the contribution of women's RMG employment to women's empowerment is to be assessed. A recent analysis of the meaning of women's empowerment among key actors in Bangladesh concluded that the focus was predominantly on individual and economic empowerment, and that this was at the cost of more collective and more political forms of power. In common with other recent analyses of the meaning of women's empowerment within development globally, the paper concluded that the understanding of women's empowerment was a neutered idea of power as 'choice'. In particular, it excluded recognition of the central importance of women's political and collective empowerment in achieving fuller forms of gender equality. ${ }^{6}$ Apart from the Bangladeshi women's movement, the key actors studied - NGOs, donors, political parties - all to greater or lesser degrees featured a 'residual instrumentalism' in their view of the pathways to gender equality in Bangladesh (Nazneen et al. 2011).

The perspective from the women's movement, by contrast, was of a more multi-dimensional understanding of the kind of power women need to gain in order to secure their rights on a lasting basis, and not merely to the extent that this serves the interests of the nation more generally. This included, in addition to individual women's agency and economic empowerment, recognition of the need for collective and political empowerment, so as to jointly shift the 'structures of constraint' (Folbre 1994; Kabeer 1997) within which all women operate. The paper concluded that inadequate and potentially reversible progress towards gender equality in Bangladesh required tackling the structural political, institutional and cultural changes that mark the 'second generation' challenges to Bangladeshi women's progress. These have not often come into view as critical determinants of empowerment to date.

In an effort to contribute to the widening of the debate about the empowerment of women in Bangladesh, the analysis in this paper proposes to explore the effects of the RMG across the domains of women's empowerment, looking at not only the individual and economic forms of power that women have gained, but also the more explicitly feminist concerns of collective and political power. So to a substantial degree, the present paper provides the empirical analysis of the theoretical arguments set out by the author and colleagues in Nazneen et al. 2011). The paper will proceed with its empirical analysis by discussing the effects of RMG employment on women's citizenship, access to basic education, rights to public space, and political empowerment. 


\section{The RMG sector}

Some background to the RMG sector is necessary. A history of the emergence and growth of the sector is available from other sources, ${ }^{7}$ so we focus here on the contemporary economic, political and social significance of the RMG sector. The history of the RMG sector in Bangladesh resembles that of most low income country expansions into export manufacturing with the global restructuring of the garments trade, enabled by trade liberalisation and low labour costs, with some local variants. Several features of the growth and development of the RMG sector are worth noting, however. It emerged initially in response to the Multifibre Arrangement (MFA) in 1974, which set quotas on garments exports from the newly industrialising countries of Asia, and encouraged 'quota-hopping' as entrepreneurs sought to establish manufacturing sites in quota-free sites. The Korean firm Daewoo was an early entrant in Bangladesh, when it came to an agreement with a Bangladeshi firm, Desh Garments, to which it trained and provided equipment (Kabeer and Mahmud 2004). Nationally, economic reform processes were also in train from the early 1980s to reverse the socialist and state-directed thrust of economic policy, abandoning import substitution industrial policies in favour of promoting export-led growth. This was most marked under the National Industrial Policy in 1982, which set up incentives and support for foreign direct investment, including through export processing zones (EPZs) (Kabeer and Mahmud 2004; Kochanek 1993).

The 1990s saw more incentives for RMG investment, encouraging the growth of more locally-owned firms (Bhattacharya and Rahman 2000). Early on, domestic entrepreneurs typically drew on their client networks in their home areas to mobilise their initial workforce. There was a paternalistic aspect to some of this, as the factory owner essentially undertook the protection of women workers from these areas (Kabeer 2000). Early on, the strategy of employing women appears to have been aimed in part at circumventing the possibility of labour organisation, as the chief lesson from the state-owned enterprises was that this made it impossible to run a profitable business. Women were seen as likely to be docile, and this, with the extreme cheapness of their labour, made an emphasis on women's employment more likely (Kabeer 2000). An idea that tailoring was in some sense customarily or at least appropriately women's work may have contributed to the social acceptability of what was, in effect, tailoring. But as an explanation of why more conservative rural households accepted girls' garments work, this has not generally been accepted by leading scholars in the field, who note that tailoring is a traditionally male occupation. RMG employment had no important opponents and many potential beneficiaries, so that whether or not public policy was overtly supportive, it did not deter women's employment, even during shifts towards more Islamic versions of the state in the 1980s.

Despite employers' concerns that male workers may be more militant and organised, the more recent emergence of the knitwear industry has been on the basis of a considerably more male workforce (as knitting machines are seen as too heavy and/or too complex for women). The implications of the changing gender and skills of the export labour force have not been very thoroughly considered to date. It is surprising, for instance, that the changing gender composition of the workforce did not make developing more constructive workerowner-state relationships a higher priority. 


\subsection{The economic significance of the RMG sector}

It is difficult to overstate the contemporary significance of the RMG sector in Bangladesh's economic development. With around 1.9 million workers directly employed in the sector (Ahmed 2009), it employs only 4 per cent of the total labour force of 51.8 million, over onethird of the 5.3 million in manufacturing employment (Rahman, Moazzem and Hossain 2009). Yet some 76 per cent of all export earnings were from apparel in 2008-9 (MoF 2009, chapter 6 ), and a 2002 estimate was that the RMG sector contributed some 10 per cent of GDP (Bhattacharya, Rahman and Raihan 2002).

Its central significance for the national economy means its continued growth has been a key public policy concern. The industry has faced several challenges, but to date has proven to be remarkably adaptive to its global market environment. The episodes include the US Harkin Bill to prevent use of child labour in the early 1990s, the shock to global trade which hit exports to the US (a major market for Bangladeshi garments) after 9/11 (see Siddique 2003; Ward et al. 2004); and the end of the favourable Multi Fibre Arrangement in 2005, which exposed Bangladesh's sector to more competition, including from China (Ahmed 2009).

More recently, the sector has recovered well from the global downturn of 2008-10. It did not go untouched: garments exports contracted substantially in the first half of the 2009-10, but this was compared to unprecedentedly rapid growth the previous year. The industry was hit somewhat less and later than export sectors elsewhere, very likely because the Bangladeshi industry benefited (in order volumes) from downward pressure on prices - the so-called 'WalMart effect' (Rahman, Bhattacharya et al. 2009; CPD 2011). But the idea that the sector's continued success depends solely on 'a race to the bottom', and rests on Bangladesh's continued capacity to compete amidst downward wage pressures now lacks credibility. One reason is that a process of restructuring is already happening, and there is evidence of improvements in compliance and management practices to raise worker productivity in the modern sections of the industry (Rahman et al. 2007; MoF 2009; CPD 2011). There are signs that these improved managerial and compliance practices are enabling investments in worker productivity, helping factories cope with the uncertainties of export production in Bangladesh (political and labour unrest, transport, energy and other infrastructural bottlenecks).

Other changes afoot include new Rules of Origin that may be opening up new opportunities in the European market and the expansion of the Asian market for Bangladeshi garments. Changes to the Indian trade regime may also favour RMG exports from Bangladesh, as should the global economic recovery more generally (CPD 2011).

\subsection{The political significance of the RMG sector}

Economic significance is accompanied by its growing political significance as a wellorganised and resourced and relatively unified interest group. The first generation RMG owners were mainly from the professional middle classes - engineers and civil servants, factory managers and technicians (see Kabeer and Mahmud 2004). The growth of the RMG and the establishment of the Bangladesh Garments Manufacturers and Exporters Association (the BGMEA) and later the Bangladesh Knitwear Manufacturers and Exporters Association (BKMEA) marked the first real entry of organised business interests (as distinct from more particularistic interests) within the Bangladeshi polity. Business in the region had historically been dominated by non-Bengali Muslims prior to Independence, so that the RMG owners collectively represented the emergence of a distinct indigenous entrepreneurial class (see Sobhan and Sen 1988; Kochanek 1993). Most notably through the BGMEA, business interests began to organise for political influence through the 1990s (see Kochanek 1996 and 2000). It is also significant that a high proportion of national politicians are drawn from business and industry (57 and 56 per cent in the previous and present parliaments 
respectively), ${ }^{8}$ replacing the mainly urban professional middle class politicians from the independence era (see Khan et al. 1996; IGS 2006). While a figure for the number of RMG owners among the business people in parliament is not available, the prominence of garments manufacturing within the business sector as a whole in Bangladesh suggests that it is likely that a significant proportion has personal interests or close connections with the industry.

Persistent infrastructural bottlenecks (problems of electricity, gas, transport, the Chittagong Port) underpinned by problems of governance (grand and petty corruption, slow procurement and investment, labour unrest and political violence) plague the lead times of garments exports. ${ }^{9}$ There is potential for BGMEA to act as a lobbying power for the greater good of manufacturing interests and the general public, particularly in relation to energy supply and infrastructural investment. Yet optimism that the relatively powerful BGMEA, with its high degree of insulation from national politics afforded by its position as lead exporter (IGS 2006), might exert positive pressures on economic governance has not to date been realised.

Instead, where the BGMEA has weighed in on governance concerns, it has mainly attempted to insulate the industry from them, rather than forcing a political settlement on improved governance of wider public benefit. An example is the political parties' concession to exempt garments factories from hartal (the all-out strikes that are the main weapon of the political opposition within Bangladeshi politics) in the 1990s, which in theory should have permitted export production to continue unhindered. ${ }^{10}$ The BGMEA has also been successful in attracting special concessions and incentives. This was illustrated most clearly in the fiscal stimulus response to the global financial crisis as it began to unfold in Bangladesh in 2009. Compared to the primary exporters, the early phase of the crisis saw the RMG sector affected through dropping garment prices globally, but saw order volumes rise with the 'WalMart effect'. The sector felt excluded from the first fiscal stimulus package of \$488 million in April 2009, and lobbied successfully for more support as garments export growth declined in the first half of the 2009-2010 financial year (Rahman et al. 2010). But it was not until the third stimulus package that its lobbying bore fruit with a wide-ranging set of incentives to help the industry through the crisis, focused on cash incentives and easing the costs of business (MoF 2009). However, efforts to extract government cash to pay wages and Eid bonuses in 2009 were embarrassingly shot down, with the Government dismissing industry warnings that without help with paying wages and bonuses labour unrest would result, citing statistics showing the sector's continued profitability. The BGMEA denied trying to blackmail the government, and as the leading English language newspaper put it, was forced to eat 'humble stimulus pie'. ${ }^{11}$

The limits to the political clout of the BGMEA are becoming increasingly clear, for two reasons. One is that it is widely believed that since the 2000s, the leadership of the sector has become more closely aligned to party interests. This may ensure greater access to the seats of power, but it also compromises its autonomy with respect to public policy. ${ }^{12}$ The second may be equally important, and this is the limits on the political influence of the BGMEA from what appears to be widespread popular sympathy with the RMG workers'

\footnotetext{
$8 \quad$ Personal communication from Inge Amundsen of Chr. Michelsen Institute.

$9 \quad$ Bhattacharya and Rahman (2000) note that partly because of the need to import raw materials, lead times in RMG manufacture in Bangladesh are some 120-150 days, compared to only 19-45 days in Sri Lanka, and 12 in India. More recent estimates were that lead times for woven garments were in the 90-130 day range (Nuruzzaman and Haque 2009; Haider 2007; World Bank 2005). But it explains why so many vehicles on Dhaka streets at this time carried signs explaining that they were engaged in 'urgent export work', to signal their exclusion from potential political violence.

11 'BGMEA eats humble stimulus pie', 8 September 2009, The Daily Star.

12 This insight arises from interviews conducted with garments factory owners including some active within the BGMEA, as part of a multi-donor country governance assessment in 2010.
} 
longstanding struggle for decent (and regular) wages. This is a complicated issue that merits far more sustained attention than it has received to date. Several aspects of the popular perception of this struggle merit attention. The first is that for many within the business elite, wage struggles and rights of labour to organise spell the doom of the industry, as organised labour is seen to have captured key (mainly public sector) industries in the past. There is a marked tendency among the RMG owner classes to detect the outside hand of economically powerful regional neighbours seeking to sabotage this nationally important sector, with much dark reference to 'vested quarters' and outside actors manipulating otherwise compliant workers. Such views are dismissive of the workers' struggle.

In the popular and middle class perspective, however, the gap between the conspicuous consumption of the garments-owning classes and the pitiful pay packets of these young workers has become a glaring inequality. Sympathetic literary, journalistic and other depictions of Bangladeshi garment workers may have heightened this awareness, although this appears to be more the preserve of elite and English-language culture than mass or popular culture (see also Kabeer and Mahmud 2004). ${ }^{13}$ That RMG sector employment has meant a reduction in the supply of women's and girls' domestic labour has caused considerable hardship to middle class households, and in particular to working women; this is very likely to moderate their sympathies and support. ${ }^{14}$ Yet while there is no middle class support for worker violence, there is certainly widespread awareness within this group of the rising cost of living since the mid-2000s and so some recognition of the legitimacy of their struggle (if not their methods). As food prices spiked in 2008 and 2011 the issue of low wages has remained a concern with which all urban people can sympathise (see Hossain et al. 2009; Hossain et al. 2010).

Governments have responded in a series of ways since 2006. Efforts by the state to put down protests have achieved little. The introduction of the Industrial Police is part of the effort to prevent unrest, although workers generally report that labour organisation more generally is repressed. The priorities of the state with respect to garment workers is highlighted by this innovation, which was not intended to police worker behaviour, rather than to protect workers against the harassment and abuse they routinely face in and en route to work (Siddiqi 2003). The present Awami League Government has to date been more responsive to the garment workers' demands than some previous regimes, and the minimum wage was fixed at Tk 3000 in 2009. Yet the struggle continues in some sections of the growing RMG labour movement, with claims for a Tk 5000 minimum wage now being argued for. While the present campaign dates at least to the May 2006 incidents which involved violence, arson and criminal damage, violent actions continue within the sector, reinforcing the need for more regular channels of labour-industry dialogue and policy-making processes.

\section{Women as RMG workers}

We turn now to women's experiences as RMG workers. This section will explore two apparently contradictory issues about women's garment work experience. The first is the tough and exploitative nature of garments work; such work has always been tough physically demanding and featuring unsafe conditions of fire risks, sexual harassment and physical and verbal abuse. By virtue of their gender, women typically enter the industry on terms of comparative disadvantage in terms of pay, conditions and promotion prospects. Irregular wage, overtime and bonus payments have long been and remain one of the most

\footnotetext{
13 For example, Monica Ali's somewhat controversial Brick Lane, itself inspired by Naila Kabeer's The Power to Choose (2000). Sohela Nazneen reports that a search for popular representations of women garments workers in songs, films etc returned relatively few examples, suggesting this is a glaring gap in popular cultural representations of the heroines of the country's export industry! 
significant problems workers face in the industry. All of this has meant that until recently, few women garments workers stayed longer than five years, with their garments career usually overlapping with their pre- and early marriage lives. Most women find it difficult to balance care work with garments employment, which involves long working days and unpredictable over-time; facilities for childcare are rare, as is return to work within the same factory after maternity.

Yet the hard nature of garments work appears to be contradicted by the second issue about women's RMG employment which is that despite its hardship, women and girls who have worked in the sector have experienced a range of forms of social and economic empowerment as a result of that work. The important issue here is that these findings highlight the relative advantages afforded by RMG employment within the context of women's limited labour market opportunities in Bangladesh.

\subsection{Hard work}

Women make up the majority of workers in the RMG sector as a whole, with most recent estimates suggesting that up to 1.7 million women are employed in the sector at present (Ahmed 2009). ${ }^{15}$ The gender composition of the apparels sector workforce has changed in recent years, with the growth of the knitwear industry which employs more men. That knitwear manufacturing is seen as 'men's work' has been linked to the belief that women are less capable of the physical and skill demands of the machinery used in knitwear and sweater production. Women and girl workers are concentrated in the woven RMG sector, in which the gendered pattern of the occupation structure is that senior management, supervisors and occupations seen as skilled technicians (e.g., cutters, finishers) tend to be men; most machine operators and helpers are women and girls. Siddiqi summarises the gendered hierarchy of production:

Production is divided into three main tasks - cutting, sewing and finishing. A production manager (PM), almost always male, is in charge of the entire production process from cutting to shipment, and reports only to the managing director. The cutting section is supervised by a male master cutter (cutting master) under whom other cutters and helpers, all male, work. The responsibility of overseeing the entire sewing section is in the hands of the floor-in-charge, as he or she is called. The floor-in-charge of sewing is preferably a woman, 'so that the workers will feel comfortable bringing their problems to her'. Almost three quarters of the line supervisors in the sewing section are men ... The sewing machine operators and helpers are predominantly female, around 80 per cent. In the finishing section, the floor-in-charge is always male, as are line supervisors and those who do the ironing. Folding is done by men and women. Male workers do the packaging and cartoning (2000: L-13).

The force of gender segmentation within the RMG industry means that women who do jobs that are seen as more skilled - and therefore as 'men's' jobs - can be ashamed of their 'unfeminine work' (Kabeer 1991b). Most recent survey data suggests that occupation segregation is less acute in the more 'modern' EPZs than in the non-EPZ factories (see Table 3).

It may be a feature of the informality of the industry that reliable up-to-date worker data is hard to come by for the RMG sector. Estimates of the proportion of women workers in the sector vary widely, from 66 (Paul-Majumder and Begum 2000) to 90 percent (Ahmed 2009). Given the growing importance of the knitwear industry and its predominantly male workforce within the RMG sector as a whole, the lower figure is likely to be closer to the truth in the present day. 
Table 3.1 Gender division of RMG jobs (\% of workers)

\begin{tabular}{|l|l|l|l|l|}
\hline Job & \multicolumn{2}{|c|}{ EPZ } & \multicolumn{2}{c|}{ Non-EPZ } \\
\hline & Men & Women & Men & Women \\
\hline Operator & 70 & 54.5 & 54.5 & 77.3 \\
\hline Helper & 20 & 27.3 & - & 4.5 \\
\hline Packer & - & - & - & 6.8 \\
\hline Other & 10 & 18.2 & 45.5 & 11.4 \\
\hline All & 100 & 100 & 100 & 100 \\
\hline
\end{tabular}

Source: CPD/GATE survey, in Khatun et al. (2007).

Gender segregation within the RMG occupation hierarchy is reflected in gender wage differentials. The CPD/GATE survey found that wage differentials remained significant (indeed, they may have increased over time) in the RMG industry, with women machinists or operators earning only 71 per cent of the earnings of men operators; female helpers earned a mere 53 per cent of male helpers' earnings in 2005. Only in 'other' categories of work ironing, folding, cleaning and packing - were wage differentials slightly in favour of women (103 per cent) (Khatun et al. 2007: 42). Yet promotion prospects were generally dim for most women workers (Chaudhuri Zohir and Paul-Majumder 1996). Analysis indicates that simple discrimination explained part of the wage differential and that the wage gap may have increased over time (see also Paul-Majumder and Begum 2000; 2006; Paul-Majumder 2003). This is despite the fact that skill differentials tend to explain more of the gender wage differentials in the RMG than in other sectors (Ahmed and Maitra 2010; Kapsos 2008; Uddin 2008). However, despite strong evidence that simple discrimination affects wage differentials, business leaders, policymakers and trade unionists persist in the view that skill differentials entirely explain women's lower pay (see CPD 2007).

Garments work has not been a life-time career for most women who have worked in it. Women tend to be young when they work in the garments, and in the 1990s lasted an average of four years (Paul-Majumder 1996). However, there are some signs of change. The average age of women garment workers appears to have risen since the 1990s, from 19 in 1990 to 25 in 2006 (Khatun et al. 2007). The proportion of married women also increased, from 38 per cent in 1990 and 1997, to 59 per cent in the 2006 CPD/GATE survey (Khatun et al. 2007). This suggests more enduring factory careers. Yet the overall pattern remains of a very young female workforce (60 per cent under 25 in the CPD/GATE survey (Khatun et al. 2007; see also CPD 2007).

It is also the case that factory work has not provided stable, respectable industrial jobs, although EPZ employment comes closer to that ideal than employment in other kinds of factories. Export sector factory work under the New International Division of Labour needs to be situated on the continuum between formal and informal work (Kabeer and Mahmud 2004b). The labour contract is certainly an informalised and fluid arrangement between factories and workers, enabled in part by the absence of recruitment costs in a context of no training and a steady supply of adequately schooled and 'unencumbered' labour. Demands for identification cards and contract letters and other formalising aspects commonly feature among the demands of garment workers, who appear to see these as tools with which to formalise their unevenly honoured claims to wages, overtime and benefits.

Other reasons these are not good working class jobs include issues of worker safety. Factory fires occur regularly, despite the provision of fire escapes and safety equipment having been made mandatory and among buyers' compliance requirements. Many young workers have died because of being locked inside to prevent theft of materials or to meet deadlines. In a 
particularly tragic recent event, a large, established factory caught fire in December 2010, and 26 people died -23 from jumping out of the $11^{\text {th }}$ floor windows - and around 100 people were injured. ${ }^{16}$ In one estimate, some 60 per cent of garment factories continue to lack fire safety equipment, ${ }^{17}$ despite extensive and growing pressure for factories to comply with social and labour requirements.

Garments work is also so physically demanding that few people can last more than a few years. Chaudhuri Zohir and Paul-Majumder found a higher incidence of illness among women workers than among men. These ranged from eye and head pains, to respiratory and gastric conditions and urine infections (1996). The high turnover rate of workers was attributed partly to 'sustained exhaustion from work' (pp. 101), a finding that other research has corroborated.

An important but typically neglected aspect of the lack of safety at work is that factories and routes to work can be significant sites of sexual harassment and other forms of abuse, consistent with the fact that paid work outside the house remains an anomaly albeit increasingly common. Verbal and other forms of abuse within factories were found to negatively affect the productivity of almost half of surveyed workers, and practices appear to be widespread (see Siddiqi 2003). Yet as table 4 suggests, sexual harassment and others sources of threats to personal security are actually more common during travel to and from than in the workplace, although some workers also feel insecure at home, particularly if they live in 'mess' arrangements (Chaudhuri Zohir and Paul-Majumder 1996). Siddiqi cites a 2002 media survey which found media reports of 51 rapes of working women in the first half of the year, 31 of whom were garments workers (2003). The characteristics of export manufacturing employment in Bangladesh - late working hours, inadequate transport and insecurity in the commute between work and home - create the conditions under which sexual harassment and sexual violence thrive. The 2000 Violence against Women and Children Act included reference to sexual harassment for the first time (ibid.).

Table 3.2 Workers' reports of incidents that contribute to insecurity (\% of workers)

\begin{tabular}{|c|c|c|c|c|}
\hline \multirow[t]{2}{*}{ Incident } & \multicolumn{2}{|c|}{ Experienced by self } & \multicolumn{2}{|c|}{ Experienced by colleagues } \\
\hline & Men & Women & Men & Women \\
\hline Beating in factory & 3.3 & 5.9 & 6.5 & 5.6 \\
\hline Rape in factory & - & 0.2 & - & 2.1 \\
\hline Attacked by mastaan (gangster) & 9.8 & 4.5 & - & 10 \\
\hline Got afraid in the street & 7.3 & 14.3 & 5.7 & 7.7 \\
\hline Harassed in the street & 6.1 & 19 & - & 21.5 \\
\hline Harassed by police & 2 & 1.4 & 2 & 1.9 \\
\hline Raped in street & - & - & 3.3 & 4 \\
\hline Fear of theft & 2.9 & 4.9 & - & - \\
\hline Got afraid at home & 1.6 & 4 & - & - \\
\hline
\end{tabular}

Source: Chaudhuri Zohir and Paul-Majumder (1996; pp. 95)

As Siddiqi also notes, it is crucial to recognise and act on harassment and abuse without assuming that women are victims in need of saving from garments work (2003; 2009). Women workers have developed a wide ranging of coping strategies in response to the

$16 \quad$ '26 killed in factory fire', The Daily Star. December 15, 2010.

17 'How long will garments factories remain death traps?' The Daily Star, March 62010. 
harassment and abuse they face, and these include effective tactics for resisting such treatment (Siddiqi 2003; Dannecker 1999).

Strategies for resisting the abuses and exploitation of garments workers have begun to coalesce in labour mobilisation. It is unfortunately the case that there is relatively little recent literature on labour organisation in the RMG sector other than newspaper reports, so that a proper analysis or even a full sketch of the activities and alignments of different labour organisations is beyond the paper's scope. Industry insiders believe that unrest in the sector since 2006 is linked to the rising proportion of male workers in the flourishing knitwear sector. While this may be an important factor, it is also the case that women are involved, and in some cases at the forefront of labour struggles. That they do play their rightful role challenges ideas about women's docility and weak fallback position as deterrents against their organisation (Chaudhuri Zohir and Paul-Majumder 1996; Zaman 2001; Siddiqi 2000). ${ }^{18}$

Bangladesh industrial trade unions have historically been associated with the public sector, are male-dominated, and are often closely linked to political parties. They have been generally seen in the social science literature as party-dominated interest groups with limited engagement in promoting wider public or collective member interests. Yet there are signs of change:

The trade unions are overwhelmingly male-dominated, reproducing within their leadership and rank-and-file membership the patriarchal attitudes of the wider society. Few have been willing to take up 'women's issues' seriously - harassment on the streets and within factories, proper toilet facilities, maternity leave and childcare. This appears to be changing, as a number of the more progressive unions have sought to set up 'women's wings' which deal more sensitively with women workers ... There may be also greater support from workers and management for enterprise-based unions which respond to the needs of workers within their factories rather than seeking to represent the interests of political parties.

(Kabeer and Mahmud 2004b: 153)

Trade unions were prohibited in the EPZs until the 2004 EPZ Act, and recent official statements indicate that in the absence of sanctioned forms of trade union activity, garment workers have been forced into violent action to make their claims. Quieter, less welldocumented forms of association and mutual support have also developed, through neighbourhood-level associations of workers (Mahmud and Kabeer 2006; However, factory owners continue to discourage or repress efforts to organise workers, and to see the extension of rights to organise as the beginning of the end for the garment industry of Bangladesh.

\subsection{Workers' experiences of economic and social empowerment through garments work}

If garments work is so tough and exploitative, why did so many millions of Bangladesh women break with custom and the powerful rules of female segregation to take up factory work since the late 1970s? In this section we review the literature on the changes in women's lives associated with garments work.

The abundant qualitative evidence of the motivations of women and girls for migrating from rural areas to the cities to take up paid garments work clearly identifies economic need as the driving force (see Amin et al. 1997; Kabeer 1991b; 2000; Kabeer and Mahmud 2004a; Kibria 1995; 1998; Feldman 2009). Yet economic need encompasses a wide diversity of

18 The visual record of women workers' struggles and the violent police response makes this point particularly well: see the Reuters' photographer Andrew Biraj's collection The Fashion Victims: www.andrewbiraj.com/gal2.php?pt=The Fashion Victims 
explanations and meanings and types of household condition, and does not mean that women have been forced into such employment. ${ }^{19}$

The vital point to emerge is that for women from across a wide range of household types, garments work meant a meaningful expansion of their agency at particular moments in their lives, and that earning their own wage was central to this sense of agency. Kibria emphasises the diversity of households and women's motivations for entering garments work, noting that while the most common explanation for such work in her 1998 study was family survival, some women saw garments work as enabling investment in the future (for example children's or sibling's education), while others, mainly unmarried women, saw it as enabling them to look after themselves to relieve families of the burdens of looking after adult daughters. This is partly explained in terms of reducing the burden on parents of dowry, by women earning towards them themselves or marrying without. As one young woman explained it:

If you work in garments you can better yourself. What's the use of sitting at home? If I lived in the village I would be married by now, but I'm glad that my life is different. Because I'm self-sufficient I can go where I want and marry whom I want. Even after I'm married, I will continue to live my life in my own way.

(Kibria 1995: 304)

Other explanations included the desire to avoid unwanted marriages, male attention or family conflict, and as is suggested by the above, for personal autonomy (Kibria 1998; see also Kabeer 1991b; 2000).

It is clear that for many of the women at least in the earlier decades of the industry, the decision to take up garments work was difficult because it involved conflict or tension with (generally men) family members, or with women's and society's own values and ideologies about women's mobility and work. For women with stricter interpretations of social rules, garments work meant painful choices:

I am in need, that is why I have come to work, otherwise I would have stayed at home, done namaaz-roza [prayer and fasting]. I feel bad, but what can I do, I have to live somehow ... But we are being sinful because it is a sin if other men see you. That I walk through the streets is a sin.

(Kabeer 2000: 88)

Some particularly insightful analyses explore how women have sought to accommodate what appears to be a straightforward clash of culture with the economic imperatives they felt they faced. ${ }^{20}$ This was a time when Bangladeshi women began to redefine and negotiate the terms of purdah, ${ }^{21}$ typically reinterpreting it as a state of mind in contrast to its customary expression as physical seclusion in private space (Kabeer 2000; Feldman 2009). Examples were given above of how women negotiate the treacherous public spaces in which they routinely face 'eve-teasing' and other serious forms of harassment. Women reinterpret the meanings of purdah in ways that make sense in their lives, sometimes as a code of behaviour with relatively few restrictions on personal mobility. Other more visible forms of renegotiation can be found in the multiple fashions of women's clothes and coverings that

$19 \quad$ Hussain (2010), for example, describes the situation as follows: 'A cheap labour market is created for women in Bangladesh, who are increasingly dragged into the garment sector. Female garment workers suffer from bad working conditions, few rights, and no social security or sustainable livelihood' pp. 328. dopes or rational fools'.

21 Amin explains that purdah has often been mis-specified as the superficial matter of women hiding their faces and body She defines it instead as 'the broader set of norms and regulations that promote the seclusion of women, enforce their exclusion from public spaces, and give specific gender identities to labour (1997: 219). See also Rozario (1992). 
can now be seen on the streets, whereas there were once only children and women in burkahs, if at all. Some close-grained accounts offer valuable testimony of the strategies and meanings behind a revolutionary shift in the material basis of gender relations, diplomatically cloaked by many women under an apparently orthodox interpretation.

\subsection{Women's wages and male power}

It is clear from these accounts that the economic dimension of their empowerment is central, and that the terms and degree of their control of their incomes matter. But it is difficult to arrive at a clear answer about how much control over wages garments workers typically retain, because this varies greatly. Kibria identifies a range of levels and types of women's control over their income from garments work. This included male-dominant households in which women handed over their wages without question, to lower middle class households in which women were permitted to retain earnings, to situations in which workers had total control over wages. The class and social differences between types of households made all the difference to how and whether income control was exerted. Kibria notes that while

[F]ear of men's withdrawal from their familial economic responsibilities caused women to hand over their wages, it also, somewhat ironically, encouraged women to covertly withhold a portion of their pay from the male household heads (1995: 299).

In relation to women's choices in relation to work, Kabeer similarly distinguishes among the varied motivations and social contexts from which Bangladeshi women come, identifying differences along the dimensions of whether their agency was reluctant or active, and whether their decision making involved conflict, contestation or consensus (2000). A vital factor in Kabeer's analysis is recognition of the fact that regardless of women's capacities to actually access paid work and the benefits of that work, the importance of male protection features at the base of all such choices. As one interviewee explained 'the fear that women have' of being without male protection made it unlikely that such choices would include those which would alienate men $(1997 ; 2000)$ :

This generalized insecurity, 'the fear that women have'... explained why in so many of the cases we examined, women chose not to exercise control over their incomes, let alone make choices which could threaten the established norms and practices of male privilege within the household. On the contrary, there were far more examples of a systematic effort to deny that wages had made any real difference to the balance of power within the household.

(Kabeer 1997: 297)

It is well known that without male protectors, particularly fathers or husbands, women can be extremely vulnerable in Bangladesh, as the state affords little protection. This ensures a form of male power that to some extent overshadows the empowerment potential of a mere wage. In such a context, some quite strategic thinking has probably gone into decisions around the control of the wage. Yet it is also clear from some of this body of work that male attitudes towards this income and the benefits it brings to the family unit also vary, with some threatened by this challenge to their meagre authority, and others open to a more equitable arrangement regarding resources.

An important message is that the limits to women's empowerment through individual economic means are set within the structures of what remains a patriarchal society with powerful institutions of male privilege. Yet very clearly, as the garments workers have shown, there is ample room for negotiation and manoeuvre within those structures, partly because men's attitudes also adapt. 
Somewhat less attention has been paid to date to the social effects of women's work in the garments. As will be discussed below, one broader effect has been to feminise urban public space - an effect felt positively by all Bangladeshi women. But for workers themselves, factory work has been an opportunity to learn more about the world beyond the confines of the village; to work in a modern, fast-changing sector, connected to the rest of the world and prominently alluded to by Governments and the media; to make friends and form associations beyond immediate kin groups; and to have and exercise choice in relation to romance and marriage (Kabeer 2000; Kibria 1998; Dannecker 1999).

\section{The wider effects of RMG employment}

We turn now to a discussion of the wider effects of RMG employment on gender equality and empowerment in Bangladesh. On this issue, it is important to note that we lack the rich, close-up accounts that the qualitative research into women's experiences of factory work have afforded. To some degree, this section is based on informed speculation by experts in the field ${ }^{22}$ and the fragmentary secondary and anecdotal evidence drawn from a range of sources. This means it should be read as an attempt to formulate hypotheses rather than as a fully developed argument. The importance of this section is that it enables a fuller analysis of empowerment in the collective and political senses that are typically excluded from accounts of women's empowerment in Bangladesh, as noted above.

\subsection{The impact on men's attitudes}

It is worth noting first that there has been both social disapproval of women's factory work amongst groups opposed to gender equality, as well as longstanding scepticism about the extent of women's empowerment from feminists and other progressive groups. ${ }^{23}$ The widelyheld view is that women's work in the garments industry is symbolic of the social problems of contemporary Bangladesh: ${ }^{24}$

People say that if we vote for the Jamaat, the garment factories will be shut down. Why should they be shut down? Men and women will simply have separate garments factories! People tell garments workers that they will lose their jobs if they vote for the Jamaat.

(Interview with a woman Jamaat-i-Islami supporter in Dhaka, Shehabuddin 2008: 597)

However, there is also a relatively widespread acceptance of the view that economic need justifies women's paid work in the garments factories. Recent research suggests this even includes acceptance by religious clerics and the religious right. ${ }^{25}$

Women workers also face widespread criticism and suspicion of their morals on the basis that they lack male protection, and are mobile, including at night (Siddiqi 2000). Garments work has never really had the wider society's respect as a form of women's work, for a number of possible reasons. This means mainly that men's attitudes towards garments workers have not been notably progressive: the popular view questions the virtue of women

For example, Bhattacharya, Rahman and Raihan (2002); Mahmud (2003).

For example, Rozario and Samuel note that 'Economic transformations in Bangladesh, including the growth of the garments industry and of NGO employment, have opened up extensive possibilities for new economic roles for women, but the dominant Bangladeshi culture of gender has remained relatively little altered by these developments' (2010: 357). Also Rozario (2001).

24 See also Karim (2004) for an example of the symbolism of the garments trade in the politics of the religious right.

25 See Mirza Hassan's (2009) film 'Tales of Freedom: Part 1' (www.youtube.com/watch?v=JN9JErdK7As). As yet unpublished research on 'women in the right' led by Samia Huq and Sohela Nazneen at BRAC Development Institute has uncovered these findings. 
workers, just as it generally assumes women in public spaces to be more sexually available. This reflects the assumption across South Asia that women in public space are fair game for male abuse and can safely be assumed to be of 'loose morals' or without male protection. ${ }^{26}$ The level of harassment described by garments workers in the survey and qualitative research must prove an intolerable strain, and sometimes worse. Harassment and abuse within factories has long been a concern, particularly in the poorly run smaller (often called bangla factories) suppliers. Bigger factories are often credited with better working conditions, which include more rule-bound behaviour by managers. Yet the more generalised phenomena of harassment and violence against women has affected women in the garments sector very directly.

There is also some ambivalence towards the social disruption associated with the garments industry among the progressive middle classes. Urbanisation is in general not supported by the urban middle class and elite groups for a range of reasons. There is a strong cultural preference for the rural, and a fear that poor rural people become spoiled when they come to the city. This gives rise to particular concerns about young women. One NGO director explained how the opportunities of city life could lead young women astray:

These garments workers, they earn only Tk. 800 - 1200 - you should see the housing they live in. They live on potatoes and rice. Those who are the smarter type, they have a side of prostitution. One girl who used to work in [the NGO headed by the speaker], I met her in the street, and she was hiding her lipstick, but she claimed she has extra work, freedom, a house, and wouldn't go back to the village. It's not intentional, she was forced, mastaans [gangsters] provide them with some security. These are hard issues, I am not a moralist, but as an individual, it is hard. They earn more, and the family want her to stay there, get the money, and they keep her daughter. In this atmosphere, you can't bring up a daughter, clients will look at the daughter ... I can take a moralistic view, but if I haven't eaten for 10 days, I don't know.

(Hossain 2005)

Work by Karim (2004) and Shehabuddin (2008) similarly suggests that male attitudes within the religious right movement often treat garments work as a symbol of the failings of westerncentred development.

\subsection{RMG employment and the expansion of basic education for girls}

Despite such ambivalence about the social effects of RMG employment, there are good reasons to believe that the availability of RMG employment has shaped the demand for and the supply of education for girls. If this is true, it will have played a part in the rapid gains in gender equality in education. To date, and reflecting the predominance of girls and women as unskilled short-term workers, the effects have mainly been felt in basic (primary and lower secondary) education.

The evidence for a claim that RMG employment has directly influenced Bangladesh's education successes is admittedly limited. On the demand side, parental views on the value of girls' education are believed to have shaped by the availability of jobs for girls with at least basic schooling (Hossain and Kabeer 2003; Blunch and Das 2007). Kabeer identifies 'a revaluing of girl children and a willingness to invest in their education' among some women workers, learned from their own experiences of entry into paid work (1997: 287). An interviewee in another study asked, 
Is there anything possible today without an education? You need to be educated if you go for a job in any garment factory, if you want to start a business and even if you want to set up a shop.

(Kabeer and Mahmud 2009: 13)

A study of rural-urban migration supports the idea of a causal link between RMG employment and girls' education, noting that:

work opportunities created for the illiterate and semi-literate girls and women by the export oriented ready-made garments sector in the mid-1980s can be considered an important reason for the spread of education among poorer households and an equalizing of gender disparity in enrolment rates in rural areas. More than 90 per cent of the garment workers are rural migrants, mostly women (70-75 per cent), a large majority of whom (about 75 per cent) come from mainly landless and land-poor households. Thus, compared to slum women aged 15 and over in Dhaka who, on average, have less than one year's schooling, rural women in garment factories have 2.3 years schooling, even if they belong to landless families.

(Afsar 1999: 242) ${ }^{27}$

An analysis of the factors behind changing norms around girls' education in qualitative research similarly identifies included the garments industry as part of the wider environment shaping change in the valuation of investment in girls (Schuler 2007; Hossain and Tavakoli 2008). However, the most compelling explanation for the apparent rise in demand for girls' schooling is that of timing: the pace of educational expansion over the 1990s lagged slightly behind the expansion of women's work opportunities in the RMG sector.

There is a risk of overstating the significance of RMG employment in changing valuation of girls' schooling. For much of its history, work as a machine operator, the job the vast majority of women workers access, has required little schooling. This situation may now be changing, and higher secondary and further education are increasingly common in the better garments jobs, such as in the EPZs. ${ }^{28}$ In addition, it seems that workers with less education were retrenched before those with more education when the sector was hit by the export downturn after 9/11 (Siddique 2003).

However, qualitative studies of parental aspirations more rarely mention garments work spontaneously as a motivation for educating girls; most instead cite more high status jobs in the public sector such as teachers or health sector workers (see Arends-Kuenning and Amin 2001; Schuler 2007). This may not mean that garments employment is excluded from parental calculations, because even though not preferred work, it may still offer a reasonable fallback position for girls from low income families. The view of RMG employment as reasonable safety net employment would be consistent with the literature on the motivation of early entrants into the RMG sector. And it is also consistent with the fact that these more respectable white collar jobs for women, including NGO, private sector and public sector employment, have all become considerably more realistic options for young women with education in the 2000s (Al-Samarrai 2007), making such aspiration realistic. As garments work lacks the wide positive social perception associated with other forms of women's work, it is likely that it would not be aspired to or invested in to the same extent.

In other research, Afsar has also noted the relatively high levels of education among Bangladeshi women migrating overseas to work in export manufacturing in Malaysia and the Middle East (2004).

$28 \quad$ Khatun et al. note that some 95.4 per cent of garments workers are literate, compared to 52.8 per cent of men and 44.5 per cent of women in the wider population (2007). 
On the supply-side, timing and emphasis in education policy suggest but do not confirm that women's RMG employment has had an effect. The Government has made it clear that its education policy is at least in part about creating 'dutiful and responsible manpower with scientific outlook', in a nod to export manufacturing (Government of Bangladesh 2000). It is believed that the BGMEA was supportive of government schemes to expand girls' educational access, such as the Female Secondary Stipend programme, ${ }^{29}$ it continues to make supportive noises about the Government's education programme, and has itself a number of programmes related to female education. And the context in which the stipend programme was developed included clear awareness of the growing demand for female workers (Mahmud 2003).

\subsection{Women's mobility and the feminisation of public space}

A second dimension of the wider effects of RMG employment is the feminisation of urban public space. The social significance of the change in women's public mobility should not be underestimated, even though its effects may not be measurable. It is the single aspect of RMG employment on which all observers agree, so long as they can remember the time when city streets and other public spaces were exclusively male domains:

In 1984 I visited Bangladesh to begin research on female garment workers. The image that remains deeply embedded in my consciousness is the dramatic change that characterized the streets of Dacca since I had left the country only eighteen months earlier. Perhaps most striking were the number of women who now walked along the road, often in groups of six or more, especially after a shift change at the recently opened garment factories that dotted the streets throughout the city. The image of women dressed in cotton saris leaving work in the early evening was in stark contrast to my earlier experience when I was one of only a few, if any, women walking quickly along these same roads. It also was a change from the time when I was the only woman in a government or commercial office, or in some of the smaller fresh produce or fish markets, unchaperoned by either an older or younger male companion. At first I could hardly make sense of this now strange and different place that had been my home for five years. Was I mistaken? Did I remember incorrectly? Did I get caught by the Western image of Bangladesh and Bangladeshi women dominated by purdah (female seclusion), only to confront the everyday lives of young women struggling to make a living? How was I to understand this apparently fantastic change in the course of a mere eighteen months?

(Feldman 2001: 1097)

Zaman is similarly awed by the rapidity of this entirely unanticipated change in society: 'Every morning, between six and eight, hundreds and thousands of women garment workers in Dhaka walk through the streets - a scene not even imagined 20 years ago' (2001: 148). Other scholars similarly note the 'dramatic' change involved in women's RMG work (Amin 1997). A recent essay illustrates this remarkable change in images showing an image of $21^{\text {st }}$ century Bangladeshi women 'on the move', a world away from older images of helpless rural women in need of aid (see Rahim and Azim 2010).

Why does the feminisation of public space matter? One reason is that it helps to create a more gender equitable cultural norm by normalising women's public mobility and access to public institutions. It is by no means the case that the social restrictions on women's public mobility have been removed, but there is a clear change: women and girls have a wider menu of options and more room for manoeuvre around appropriate female behaviour than in

Samer Al-Samarrai, personal communication. No supporting documentation has yet been found for this point; the author would welcome any help with references on this point. If it is true, it is an instance of the classic Gintis and Bowles' 1976 thesis about the role of education in capitalist development. 
the past (for example, Huq 2010). Most recently, the debate has begun to focus on the meanings and uses of hijab and other variations on women's clothing and public appearance (see also Azim 2007). The policy significance of this change is that cultural constraints to gender equality are not absolute or rigid, and that women can be agents in transforming their meaning and practice.

A second reason the feminisation of public space matters is its potential significance for improving women's public safety. Sexual harassment and 'eve-teasing' are still a major problem in Bangladesh (see NHRCB 2011; World Bank 2008a; Hossain et al. 2008), but as noted above, there are also signs that these problems are beginning to be recognised for the serious impediment to women's development that they are. This includes recognition from some unexpected sources: vendors and shopkeepers interviewed for Mirza Hassan's documentary about garments workers' lives, Tales of Freedom, were sympathetic about the safety needs of garment workers, who are valuable customers, and try to create a safe environment for garments workers and women shoppers in general, particularly around Eid and other festival times. And both the BNP and the Jamaat-i-Islami political party manifestos for the 2008 election mentioned the safety of women workers, with the BNP specifically mentioning garments workers. The workers were in dialogue with the current government in 2011 over safety in the Dhaka transport system, as one of the key demands of international women's day. ${ }^{30}$

\subsection{Citizenship and political empowerment}

RMG employment also appears to have been part of the reconfiguration of women's citizenship. It has primarily been in their reproductive role that women have featured in state discourse and public policy language to date in Bangladesh. This appears to be changing, as the 2005 and 2009 PRSP documents indicate (Government of Bangladesh 2009a; 2005). Instead of being seen exclusively as the mothers of future citizens, more recent official statements recognise women as not only workers like any others, but as particularly central actors in the all-important RMG industry. Siddiqi makes this point particularly well, showing how the presence of large-scale female RMG employment has become part of the Bangladesh 'brand' by representing to the outside world a unique combination of social progress with moderate Islam (2009):

$[T]$ he Bangladesh government ... tried to capitalize on its image as a Muslim but moderate country, the second largest Muslim democracy, and a trailblazer in the emancipation of Muslim women's rights. The emerging rhetoric invoked the image of oppressed Muslim women coming out of seclusion and into the liberated world of wage labour. Officials based requests for US [trade] concessions on warnings of threats to women workers' new-found empowerment (thereby resonating with both the neo-liberal and anti-terror agendas).

(Siddiqi 2009: 165)

Garments workers also appear increasingly aware of their rights as citizens (Kabeer and Kabir (2009), and of their significance within the national economy. Nazma Akhter, a former child worker and now prominent labour leader, described garments workers as 'the new golden girls of Bengal', referring to their central role in ushering in a more prosperous age (Siddiqi 2009: 164).

The most vivid evidence of the political empowerment being experienced by women RMG workers is, however, in the continuing unrest in the sector, and the ongoing movement for a higher minimum wage. The violence and disruption to the industry have been much deplored, yet the struggle has scored notable successes to date, including an almost 
doubling of the minimum wage (although the campaign continues for a higher wage yet). Subsidised food has also been made available in the factories to protect against rising food prices, and the present Government has arguably taken a relatively more supportive position with respect to garments workers' rights than past regimes.

This is an issue with many dimensions, not all of which can be explored here. Several points are worth noting, however. One is that women on the whole continue to be disadvantaged and disinclined with respect to labour organisation, including for reasons of their status as unskilled workers in a labour surplus economy and because of the pressures applied by factory owners to prevent unionisation (Mahmud and Kabeer 2006; Zaman 2001; Rock 2003). The relative weakness of women workers' bargaining position has, however, been partly obviated by the rising numbers of men in the industry, to whose growing number the spread of labour unrest is widely attributed. Yet under conditions of the suppression of labour organisation on grounds of protecting the industry's global competitiveness, new, more localised forms of worker mobilisation have been emerging; despite their limitations, some of these may help to address women workers' immediate concerns (Kabeer and Kabir 2009).

A second factor of interest about RMG workers' political empowerment is that improvements in workers' rights appear to have been driven more by successes within national politics rather than by global campaigns to promote labour and social standards. ${ }^{31}$ There has been a shift in the enforcement of 'compliance' in the RMG industry (Mahmud and Kabeer 2006), which is enabling a more constructive engagement between workers and employers and having other positive effects on management practices within the more established and larger factories. But it is clear that such compliance remains forced on employers, as on the buyers who themselves impose it on their suppliers: it does not amount to a 'culture of compliance' or a wider recognition that raised labour standards may be in employers' interests to the extent they promote worker productivity. There remain the many informal 'sweatshop' style factories that continue to make up a large proportion of RMG production (Mahmud and Kabeer 2006).

The third factor shaping RMG workers' political empowerment is their exposure to the global economy. As is the case elsewhere, globalisation has had a range of paradoxical effects on RMG workers in Bangladesh, including that increased downward on wages in an increasingly globally competitive market has meant more jobs, and arguably more competition for garments workers over the 2000s. This has helped garments' workers gain collective power. But the limits to the 'comparative advantage of their disadvantage' are also revealed by the effects of globalisation, through the effects on their living standards of global food and fuel price volatility. These have been among the single most important motivations behind workers' demands for higher wages since 2006. It is a concern in which the wider population, particularly urban groups, can readily share (see Hossain et al. 2009; 2010). In real terms, then, globalisation has meant RMG workers' real wages declined over the 2000s, and even a doubling of the minimum wage has left them very little better off than they were in 2000. It has been principally through direct action framed in terms of intolerably high food prices that the minimum wage campaign has been staged. Its successes to date may relate to wider public sympathy in the face of the shared experience of the rising cost of living, to the present Government's traditionally closer alignment with trade unions and claims to pro-poor orientation and responsiveness with respect to food security. In this context it is also worth noting that the continued unrest in the sector does not appear to have substantially affected the sector's growth, which has rebounded remarkably in the global economic recovery. 


\section{Conclusions}

Women's RMG employment marked a dramatic shift in aspects of gender relations in Bangladesh, particularly because of its mass scale. Despite the hard and exploitative nature of garments work, women and girls have gained autonomy and greater bargaining power within households. The direct effects on women workers' lives have been varied, as women's lives and social settings are themselves diverse; but the overall picture that emerges is one of expanded choices and gains in power. This much is already known about the effects of women's garments work in Bangladesh. Less has been known of how - indeed, whether RMG employment has had wider effects beyond those of individual economic empowerment. This paper draws together the fragmentary evidence available to argue that it may well have had wider impacts on society, and is beginning now to show some changes in respect of women's citizenship and political power.

Yet these gains are all relative to the other choices for women in what remains a poor, patriarchal society. RMG employment has great potential to contribute far more to gender equality in Bangladesh. It is clear, for instance, that employers have powerful interests in supporting public policies to sustain investments in the skills of the population, particularly that of girls and women. Equally, they would benefit directly from pro-poor public policies to promote urban housing, public and particularly women's safety and freedom from harassment, improvements in urban food security, and healthcare and childcare provision. That these public policies to promote pro-poor and gender equitable change are in the interests of the RMG sector relates above all to the direction of change in the industry. All knowledgeable observers agree that the future growth and sustainability of the industry depend now on upgrading and gains in worker productivity. This is particularly urgent in a context in which further downward pressure on wages is evidently impossible, as seen in the powerful resistance against the effective cuts in real wages that resulted from rising global food prices from 2006 onwards. Sector observers and analysts are clear that in such a context, the RMG sector's continued progress depends substantially on its capacity to upgrade and raise productivity. To do this will self-evidently requires stronger public as well as private investment in workers' skills, starting with basic education for girls. It requires workplaces in which women are able to learn and practice their skills over time, to become more valuable and more effective workers over time. For that to occur, in addition to living and reliable wage and overtime payment, factory floors need to be more supportive of women's care work, so that they can balance their household work with their factory work; more concerned to ensure their dignity and respect by addressing poor management practices and sexual harassment in and en route to factories; and of their rights by enabling women workers' more meaningful dialogue and participation in policy formulation (including in education and training, public safety and transport, urban housing, safety at work); this in turn requires that women workers are able to aggregate and articulate their interests on issues that matter to them, and to work constructively with the women's movement and wider civil society.

The RMG sector can no longer rely on an endless stream of unskilled village girls for its workforce, but needs to figure out ways of retaining skilled workers and enabling them to perform better. This in turn requires greater investment in the basic education and skills of girls and women by both state and the RMG sector. It will also require the participation of women workers in dialogue and policy formulation. The main conclusion from this review is that while an earlier phase of industrial development may have generated individual economic empowerment for women, the sector's continued success depends in part on the extent to which women workers are and can be treated as full citizens of Bangladesh, with effective rights to personal safety and respect, and public policies that build and promote their skills and capacities. It will also depend on fuller recognition of their rights as workers and therefore to a collective voice. The process of women's empowerment through paid work 
in the garments industry has come of age: the demands and the needs of women workers have moved well beyond the limits of individual economic power, and into a wider but more contentious political space.

\section{Annex}

From: MoF 2009, chapter 6: The External Sector, pp. 77

Third Fiscal Stimulus package (export-focused)

*Fiscal Package in 2008-09 for immediate action:

The Government has taken the following decisions to implement the package in April- June quarter:

- Increasing cash incentive from 7.5 percent to 10 percent for jute goods;

- Increasing cash incentive from 15 percent to 17.5 percent for finished leather and leather goods;

- Increasing cash incentive from 10 percent to 12.5 percent for frozen foods and other exportable fishes. Besides, incentives for other exportable items remain the same; such as indigenous cloth, agricultural and agro processing goods; potato, bi-cycle, smashed bone, hatching egg, chickens of one day, engineering goods, liquid glucose and 100 percent halal meat.

\section{*Policy Support in 2008-09 Export Sector}

- Streamlining the cash incentive fund release procedures to ensure immediate disbursement of 70 percent of this incentive;

- The time for making down payment in respect of repayment of bank loans for exporters and yarn producers has been extended up to September 2009. Rescheduling facilities are to be extended on a case to case basis;

- Bangladesh Bank will take necessary steps for rescheduling export credit to the scheduled banks;

- The size of Export Development Fund has been increased and an individual borrower's limit also been increased to US\$1.5 million from US\$ 1 million. Credit facility will be enhanced for financing the import of machinery for plants engaged in manufacturing of exportable items.

- Extension of reduced rate of interest (7 percent) to all exportable goods and time limit for repayment has been extended to 120 days;

- Steps has been taken for rationalizing the renewal fees for captive generation of electricity; Extra surcharge has been imposed on Biman Bangladesh Airlines for transporting fruits and vegetables for price hike of fuel all over the world. Ministry of Civil Aviation has been told to request the concerned authority to reduce the rate as the price has already gone down.

- Subsidized price rice distribution program has started among the garments workers'.

- Steps have been taken to increase productivity of the frozen food sector by adopting EU acceptable standards and applying intensive cultivation technology.

- Steps have been taken to sort out the reasons for non-achieving export targets in pharmaceuticals and ceramics sector. 
The initiatives that Bangladesh Bank is pursuing and will pursue in financial sector are as follows:

- Proper attention on exchange rate in order to maintain export competitiveness of the exporters particularly to maintain a reasonable spread between REER and NEER.

- Re-fixing the rate of repo and reverse repo, SLR etc. in order to lower the interest rate imposing on advance.

\section{*Fiscal Package in FY 2009-10}

In order to tackle the adverse impact of global economic recession, the steps that the Government has already been taken will continue in the next year and the allocation will be ensured on the basis of regular monitoring. This allocation will be reflected in the budget of the next fiscal year on the basis of realities on the ground and recommendation of the Taskforce.

\section{*Policy Support in FY 2009-10 \\ Export Sector}

- Steps will be taken to impose or withdraw VAT over export.

- The Textile Institutes, Bangladesh Institute of Fashion Training and the Department of Youth will be directed and allocated money to arrange special training programs for the garments workers' required for their service in the garments factories. 


\section{References}

Afsar, R. (2004) 'Bangladeshi Women's Entry into Overseas Manufacturing: New Signals and Policy Paradigms', Feminist Review 77: 175-9

_ (1999) 'Rural-urban Dichotomy and Conference: Emerging Realities in Bangladesh', Environment and Urbanization 11: 235-46

Ahmed, F.E. (2004) 'The Rise of the Bangladesh Garment Industry: Globalization, Women Workers, and Voice', Feminist Formations 16.2: 34-45

Ahmed, N. (2009) 'Sustaining Ready-made Garment Exports from Bangladesh', Journal of Contemporary Asia 39.4: 597-618

Ahmed, N. and Peerlings, J.H.M. (2008) 'Addressing Workers' Rights in the Textile and Apparel Industries: Consequences for the Bangladesh Economy', World Development 37.3: $661-75$

Ahmed, S. and Maitra, P. (2010) 'Gender Wage Discrimination in Rural and Urban Labour Markets of Bangladesh', Oxford Development Studies 38.1: 83-112

Al-Samarrai, S. (2009) 'The Impact of Governance on Education Inequality: Evidence from Bangladesh', Public Administration and Development 28: 1-13

- (2007) 'Changes in Employment in Bangladesh, 2000-2005: The Impacts on Poverty and Gender Equity', background paper for the World Bank Poverty Assessment 2005, unpublished paper, Dhaka

Ali, R.N.; Begum, F.; Salehin, M.M. and Farid, K.S. (2008) 'Livelihood Pattern of Rural Women Garment Workers at Dhaka City', Journal of Bangladesh Agricultural University 6.2: $449-56$

Amin, S. (1997) 'The Poverty-Purdah trap in Rural Bangladesh: Implications for Women's Role in the Family', Development and Change 28: 213-33

Amin, S.; Diamond, I.; Naved, R.T. and Newby, M. (1997) 'Transition to Adulthood of Female Factory Workers: Some Evidence from Bangladesh', Population Council Paper 102

Arends-Kuenning, M. and Amin, S. (2001) 'Women's Capabilities and the Right to Education in Bangladesh', International Journal of Politics, Culture and Society 15.1: 125-42

Azim, F. (2007) 'Women and Religion in Bangladesh: New Paths', www.opendemocracy.net

- (2001) 'Formulating an Agenda for the Women's Movement: A Review of Naripokkho', Inter-Asia Cultural Studies 2.3: 389-94

Batliwala, S. (2007) 'Taking the Power Out of Empowerment - An Experiential Account', Development in Practice 17.4 and 5: 557-65

BBS (2008) Report of the Labour Force Survey Bangladesh 2005-06, Dhaka: Bangladesh Bureau of Statistics 
_ (2002) Report of the Labour Force Survey Bangladesh 1999-2000, Dhaka: Bangladesh Bureau of Statistics

Bell, S. and Newitt, K. (2010) Decent Work and Poverty Eradication: Literature Review and

Two-country Study, report prepared for the Decent Work and Labour Standards Forum, London: Ergon Associates Limited

Bhattacharya, D. and Rahman, B. (1999) Female Employment Under Export Propelled Industrialization: Prospects for Internalizing Global Opportunities in the Apparel Sector in Bangladesh, UNRISD Occasional Paper 10, Geneva: United Nations Research Institute for Social Development

Bhattacharya, D. and Rahman, M. (2000) Experience with Implementation of WTO-ATC and Implications for Bangladesh, CPD Occasional Paper Series 7, Dhaka: Centre for Policy Dialogue

Bhattacharya, D.; Rahman, M. and Raihan, A. (2002) Contribution of RMG sector to the Bangladesh Economy, CPD Occasional Paper 50, Dhaka: Centre for Policy Dialogue

Blunch, N. and Das, M.B. (2007) Changing Norms about Gender Inequality in Education: Evidence from Bangladesh, World Bank Policy Research Working Paper 4404, Washington DC: World Bank

Chaudhuri Zohir, S. and Paul-Majumder, P. (1996) Garment Workers in Bangladesh: Economic, Social and Health Condition, BIDS Research Monographs 18, Dhaka: Bangladesh Institute of Development Studies

Chowdhury, A.M.R.; Nath, S. and Choudhury, R.K. (2002) 'Enrolment at Primary Level: Gender Difference Disappears', International Journal of Educational Development 22.2: 191-203

Chowdhury, F.D. (2010) 'Middle Class Married Women's Income in Bangladesh: Who Controls it and How?', African and Asian Studies 9: 1-30

Cornwall, A.; Gideon, J. and Wilson, K. (2008) 'Introduction: Reclaiming Feminism: Gender and Neoliberalism', IDS Bulletin 39.6

CPD (2011) 'State of the Bangladesh Economy in FY2010-11 (First Reading)', draft paper, Dhaka: Centre for Policy Dialogue

_ (2010) State of the Bangladesh Economy in FY 2009-10: From Stability to Accelerated Growth, CPD Occasional Paper Series 86, Dhaka: Centre for Policy Dialogue

- (2007) 'Gender Dimension of Employment in the RMG Sector: Recent Evidence from the Field Survey', CPD Dialogue Report 89, Dhaka: Centre for Policy Dialogue

Dannecker, P. (1999) Conformity or Resistance? Women Workers in the Garment Factories in Bangladesh, Universität Bielefeld Sociology of Development Research Centre Working Paper 326, Bielefeld

Eyben, R. and Napier-Moore, R. (2009) 'Choosing Words with Care? Shifting Meanings of Women's Empowerment in International Development', Third World Quarterly 30.2: 285-300 
Feldman, S. (2001) 'Exploring Theories of Patriarchy: A Perspective from Contemporary Bangladesh', Signs 26.4: 1097-127

_ (2009) 'Historicizing Garment Manufacturing in Bangladesh: Gender, Generation, and New Regulatory Regimes', Journal of International Women's Studies 11.1: 268-88

Folbre, N. (1994) Who Pays for the Kids? Gender and the Structures of Constraint, London: Routledge

Government of Bangladesh (2009a) Steps Towards Change: National Strategy for Accelerated Poverty Reduction II: FY 2009-11, Dhaka: General Economics Division, Planning Commission, People's Republic of Bangladesh

_ (2009b) The Millennium Development Goals Bangladesh Progress Report 2009, Dhaka: General Economics Division, Planning Commission, People's Republic of Bangladesh

_ (2000) National Education Policy, Dhaka: Ministry of Education

Haider, M.Z. (2007) 'Competitiveness of the Bangladesh Ready-made Garment Industry in Major International Markets', Asia-Pacific Trade and Investment Review 3.1, June

Hossain, N. (2007) The Politics of What Works: The Case of the Vulnerable Group Development Programme in Bangladesh, CPRC Working Paper 92, Manchester: Chronic Poverty Research Centre

_ (2005) Elite Perceptions of Poverty in Bangladesh, Dhaka: University Press Limited

Hossain, N. and Kabeer, N. (2004) 'Achieving Universal Primary Education and Eliminating Gender Disparity', Economic and Political Weekly September 4, XXXIX.36:,4093-9

Hossain, N. et al. (2009) 'Accounts of Crisis: Poor People's Experiences of the Food, Fuel and Financial Crises in Five Countries, Report on a Pilot Study January-March 2009', mimeo, Brighton: IDS

- (2008) 'Crime, Violence, and Insecurity', chapter four in The State of Governance in Bangladesh 2007: Expectations, Commitments, Challenge, Dhaka: BRAC University Institute of Governance Studies

Hossain, N.; Fillaili, R.; Lubaale, G.; Mulumbi, M.; Rashid, M. and Tadros, M. (2010) 'The Social Impacts of Crisis: Findings from Community-level Research in Five Developing Countries', mimeo, Brighton: IDS

Hussain, N.A. (2010) 'Religion and Modernity: Gender and Identity Politics in Bangladesh', Women's Studies International Forum 33: 325-33

Huq, S. (2010) 'Negotiating Islam: Conservatism, Splintered Authority and Empowerment in Urban Bangladesh', IDS Bulletin 41.2: 97-105

IGS (2009) The State of Governance in Bangladesh 2008: Confrontation, Competition, Accountability, Dhaka: Institute of Governance Studies, BRAC University

_ (2006) The State of Governance in Bangladesh in 2006: Knowledge, Perceptions, Reality, Dhaka: Centre for Governance Studies (now Institute of Governance Studies), BRAC University 
Kabeer, N. (2004) ‘Globalization, Labor Standards, and Women's Rights: Dilemmas of Collective (In)action in an Interdependent World', Feminist Economics 10.1: 3-35

_ (2000) The Power to Choose: Bangladeshi Women and Labour Market Decision in London and Dhaka, London/New York: Verso

- (1997) 'Women, Wages and Intra-household Power Relations in Urban Bangladesh', Development and Change 28: 261-302

_ (1991a) 'The Quest for National Identity: Women, Islam and the State in Bangladesh', Feminist Review 37: 38-58

_ (1991b) 'Cultural Dopes or Rational Fools? Women and Labour Supply in the Bangladesh Garment Industry', The European Journal of Development Research 3.1: 133-60

Kabeer, N. and Kabir, A.H. (2009) Citizenship Narratives in the Absence of Good Governance: Voices of the Working Poor in Bangladesh, IDS Working Paper 331, Brighton: IDS

Kabeer, N. and Mahmud, S. (2009) 'Imagining the Future: Children, Education and Intergenerational Transmission of Poverty in Urban Bangladesh', IDS Bulletin 40.1: 10-21

- (2004a) 'Globalization, Gender and Poverty: Bangladeshi Women Workers in Export and Local Markets', Journal of International Development 16: 93-109

_ (2004b) 'Rags, Riches and Women Workers: Export-oriented Garment Manufacturing in Bangladesh', in M. Carr (ed.), Linking Women Producers and Workers with Global Markets, London: Commonwealth Secretariat: 133-62

Kapsos, S. (2008) The Gender Wage Gap in Bangladesh, ILO Asia-Pacific Working Paper Series, Bangkok: International Labour Organization

Karim, L. (2008) 'Demystifying Micro-Credit: The Grameen Bank, NGOs, and Neoliberalism in Bangladesh', Cultural Dynamics 20.1: 5-29

_ (2004) 'Democratizing Bangladesh: State, NGOs, and Militant Islam', Cultural Dynamics 16.2/3: 291-318

Keane, J. and de Velde, D.W. (2008) 'The Role of Textile and Clothing Industries in Growth and Development Strategies', mimeo, London: Overseas Development Institute Investment and Growth Programme

Kibria, N. (1995) 'Culture, Social Class and Income Control in the Lives of Women Garment Workers in Bangladesh', Gender and Society 9: 289-309

Khan, F.C. (2005) 'Gender Violence and Development Discourse in Bangladesh', International Social Science Journal 57.2: 219-30

Khan, S.A.; Khan, S.I. and Haque, M.I. (1996) Political Culture, Political Parties and the Democratic Transition in Bangladesh, Dhaka: Academic Publishers

Khatun, F.; Rahman, M.; Bhattacharya, D.; Moazzem, K.G. and Shahrin, A. (2007) Gender and Trade Liberalization in Bangladesh: The Case of the Ready-Made Garments, 
Greater Access to Trade Expansion (GATE) Project, United States Agency for International Development (USAID)

Khosla, N. (2009) 'The Ready-made Garments Industry in Bangladesh: A Means to Reducing Gender-based Social Exclusion of Women?', Journal of International Women's Studies 11.1: 289-303

Khundker, N. (2002) 'Garment Industry in Bangladesh', in G. Joshi (ed.), Garment Industry in South Asia: Rags or Riches? Competitiveness, Productivity and Job Quality in the Post-MFA Environment, New Delhi: International Labour Organization

Klasen, S. and Lamanna, F. (2008) The Impact of Gender Inequality in Education and Employment on Economic Growth in Developing Countries: Updates and Extensions', EUDN/WP 2008-10

Kochanek, S.A. (2000) 'The Growing Commercialization of Power', in R. Jahan (ed.), Bangladesh: Promise and Performance, London/Dhaka: Zed Books/University Press Limited

_ (1996) 'The Rise of Interest Politics in Bangladesh', Asian Survey 26.7: 704-22

_ (1993) Patron-Client Politics and Business in Bangladesh, Dhaka: University Press Limited

Mahmud, S. (2003) 'Female Secondary School Stipend Programme in Bangladesh: A Critical Assessment', mimeo, Dhaka: Bangladesh Institute of Development Studies

Mahmud, S. and Kabeer, N. (2006) 'Compliance Versus Accountability: Struggles for Dignity and Daily Bread in the Bangladesh Garment Industry', in P. Newell and J. Wheeler (eds), Rights, Resources and the Politics of Accountability, London and New York: Zed Press: 206-23

McGill, E. (2006) Trade and Gender in Bangladesh: A Legal and Regulatory Analysis, Report prepared for the Greater Access to Trade Expansion (GATE) Project, United States Agency for International Development (USAID)

MoF (2009) Bangladesh Economic Review 2009 (English), Dhaka: Ministry of Finance of the Government of the People's Republic of Bangladesh

Moghadam, V. (2003) Modernizing Women: Gender and Social Change in the Middle East, $2^{\text {nd }}$ edition, Boulder Co.: Lynne Rienner

Mookherjee, N. (2008) 'Gendered Embodiments: Mapping the Body-politic of the Raped Woman and the Nation in Bangladesh', Feminist Review 88: 36-53

Morshed, M.M. (2007) 'A Study on Labour Rights Implementation in Readymade Garment (RMG) Industry in Bangladesh: Bridging the Gap between Theory and Practice', unpublished $\mathrm{PhD}$ dissertation, University of Wollongong

Nabi, R.; Datta, D.; Chakrabarty, S.; Begum, M. and Chaudhury, N.J. (1999) 'Consultation with the Poor: Participatory Poverty Assessment in Bangladesh', mimeo, Dhaka: NGO Working Group on the World Bank

Naved, R.T. and Persson, L.A. (2010) 'Dowry and Spousal Physical Violence against Women in Bangladesh', Journal of Family Issues 31.6: 830-56 
Naved, R.T.; Azim, S.; Bhuiya, A. and Persson, L.A. (2006) 'Physical Violence by Husbands: Magnitude, Disclosure and Help-seeking Behavior of Women in Bangladesh', Social Science and Medicine 62.12: 2917-29

Nazneen S. and Sultan, M. (2010) 'Reciprocity, Distancing, and Opportunistic Overtures: Women's Organisations Negotiating Legitimacy and Space in Bangladesh', IDS Bulletin 41.2: 70-8

Nazneen, S.; Sultan, M. and Hossain, N. (2011) National Discourses on Women's Empowerment in Bangladesh: Enabling or Restricting Women's Choices?, IDS/Pathways of Women's Empowerment Research Programme Consortium Working Paper, Brighton: IDS

NHRCB (2011) Perceptions, Attitudes and Understanding: A Baseline Survey on Human Rights in Bangladesh, Dhaka: National Human Rights Commission of Bangladesh

Nuruzzaman, and Haque, A. (2009) 'Lead Time Management in the Garment Sector of Bangladesh: An Avenues for Survival and Growth', European Journal of Scientific Research 33.4: 617-29

Paul-Majumdar, P. (2003) Health Status of the Garment Workers in Bangladesh: Findings from a Survey of Employers and Employees, BIDS Research Report Series 1, Dhaka: Bangladesh Institute of Development Studies

- (1996) 'Health Impact of Women's Wage Employment: A Case Study of the Garment Industry of Bangladesh', The Bangladesh Development Studies Journal XXIV.1,2

Paul-Majumder, P. and Begum. A. (2006) Engendering Garment Industry, The Bangladesh Context, Dhaka: University Press Limited

(2000) The Gender Imbalances in the Export Oriented Garment Industry in Bangladesh, PRR Gender and Development Working Paper Series 12, Washington DC: World Bank

(1997) Upward Occupational Mobility among Female Workers in the Garment Sector in Bangladesh, BIDS Research Report 153, Dhaka: Bangladesh Institute of Development Studies

Rahman, M.; Bhattacharya, D. and Moazzem, K.G. (2007) Bangladesh's Apparel Sector in Post-MFA Period: A Benchmarking Study on the Ongoing Restructuring Process, Dhaka: Centre for Policy Dialogue

Rahman, M.; Bhattacharya, D.; Iqbal, M.A.; Khan, T.I. and Paul, T.K. (2009) Bangladesh, ODI Global Financial Crisis Discussion Series Paper 1, London: Overseas Development Institute

Rahman, M.; Iqbal, M.A.; Khan, T.I. and Dasgupta, S. (2010) Bangladesh Phase 2, ODI Global Financial Crisis Discussion Series Paper 12. London: Overseas Development Institute and Centre for Policy Dialogue

Rahman, M.; Moazzem, K.G. and Hossain, S.S. (2009) Impact of the Global Economic Crisis on the Employment and Labour Market of Bangladesh: A Preliminary Assessment, Centre for Policy Dialogue Paper 80, Dhaka: Centre for Policy Dialogue 
Rahman, R.I. (2005) The Dynamics of the Labour Market and Employment in Bangladesh: A Focus on Gender Dimensions, ILO Employment Strategy Papers 13, Geneva: International Labour Organization

Rock, M. (2003) 'Labour Conditions in the Export-oriented Garment Industry in Bangladesh', South Asia: Journal of South Asian Studies 26.3: 391-407

Rozario, S. and Samuel, G. (2010) 'Gender, Religious Change and Sustainability in Bangladesh', Women's Studies International Forum 33: 354-64

Saferworld (2008) Bangladesh Human Security Survey, London: Saferworld

Salway, S.; Jesmin, S. and Rahman, S. (2005) 'Women's Employment in Urban Bangladesh: A Challenge to Gender Identity?', Development and Change 36.2: 317-49

Salway, S.; Rahman, S. and Jesmin, S. (2003) 'A Profile of Women's Work Participation Among the Urban Poor of Dhaka', World Development 31.5: 881-901

Schuler, S.R. (2007) 'Rural Bangladesh: Sound Policies, Evolving Gender Norms, and Family Strategies', in M.A. Lewis and M.A. Lockheed (eds), Exclusion, Gender and Education: Case Studies from the Developing World, Washington DC: Center for Global Development: 179-203

Seguino, S. and Grown, C. (2006) 'Gender Equity and Globalization: Macroeconomic Policy for Developing Countries', Journal of International Development 18: 1081-104

Sen, B. and Hulme, D. (eds) (2006) Chronic Poverty in Bangladesh: Tales of Ascent, Descent, Marginality and Persistence: The State of the Poorest 2004/2005, Dhaka: Programme of Research on Chronic Poverty Bangladesh/Chronic Poverty Research Centre, University of Manchester

Shafiq, M.N. (2009) 'A Reversal of Educational Fortune? Educational Gender Gaps in Bangladesh', Journal of International Development 21: 137-55

Shehabuddin, E. (2008) 'Jamaat-i-Islami in Bangladesh: Women, Democracy and the Transformation of Islamist Politics', Modern Asian Studies 42.2/3: 577-603

Siddiqi, D.M. (2009) 'Do Bangladeshi Factory Workers need Saving? Sisterhood in the Postsweatshop Era', Feminist Review 91: 154-74

_ (2003) The Sexual Harassment of Industrial Workers: Strategies for Intervention in the Workplace and Beyond, CPD-UNFPA Paper 26, Dhaka: Centre for Policy Dialogue/United Nations Population Fund

(2000) 'Miracle Worker or Womanmachine? Tracking Transnational Realities in Bangladeshi Factories', Economic and Political Weekly 35.21/22: L11-17

Siddique, K. (2003) Deceleration in the Export Sector of Bangladesh and Women Workers: Assessing Impacts and Identifying Coping Strategies, Centre for Policy Dialogue Occasional Paper Series 26, Dhaka: Centre for Policy Dialogue

Tariquzzaman, S. and Hossain, N. (2009) 'The Boys left Behind: Where Public Policy has Failed to Prevent Child Labour in Bangladesh', IDS Bulletin 40.1: 31-7 
Uddin, M.G.S. (2008) 'Wage Productivity and Wage Income Differential in Labor Market: Evidence from RMG Sector in Bangladesh', Asian Social Science Journal 4.12: 92-101

World Bank (2008a) From Whispers to Voices: Gender and Social Transformation in Bangladesh, World Bank Bangladesh Development Series 22, Dhaka: World Bank

- (2008b) Poverty Assessment for Bangladesh: Creating Opportunities and Bridging the East-West Divide', World Bank Bangladesh Development Series 26, Dhaka: World Bank

- (2007) To the MDGs and Beyond: Accountability and Institutional Innovation in Bangladesh, World Bank Bangladesh Development Series 14, Dhaka: World Bank

— (2005) End of MFA Quotas: Key Issues and Strategic Options for Bangladesh Readymade Garment Industry, Bangladesh Development Series Paper 2, Dhaka: World Bank

Zaman, H. (2001) 'Paid Work and Socio-political Consciousness of Garment Workers in Bangladesh', Journal of Contemporary Asia 31.2: 145-60 